\title{
HUMANISMO MEDIEVAL Y HUMANISMO VERNÁCULO. OBSERVACIONES SOBRE LA OBRA CULTURAL DE ALFONSO X EL SABIO*
}

\author{
H. Salvador MarTínez \\ hsm1@nyu.edu \\ New York University
}

El trabajo intelectual de Alfonso X y todo su programa cultural para el reino debe inscribirse en el ámbito cultural del siglo XIII, dominado por el enciclopedismo didáctico que el rey cultivó con extraordinario fervor personal; de tal manera que el contenido ideológico y el entero significado histórico de su obra encajan perfectamente en esta tendencia de la época. El siglo XIII fue el siglo de las summas, u obras enciclopédicas, que acumulaban el saber en todos los campos, entre las que la Summa Theologica de Santo Tomás (h. 12251274) fue una de tantas. Alfonso $X$ mismo, a tono con su siglo, compiló cuatro, todas ellas monumentales: una suma jurídica, las Siete Partidas; una suma histórica por partida doble, la Estoria de España (EE) y la General Estoria (GE); una suma científica, los Libros del saber de astronomía en 16 libros; y finalmente, una suma poética, las Cantigas de Santa María, con más de 400 poemas, junto con varias composiciones profanas; con la particularidad de que todas estas obras, voluminosísimas, se escribieron en una lengua romance, prácticamente inexistente hasta aquel momento como lengua de cultura. Fue sin duda el quehacer del Rey Sabio en todos los campos del saber lo que impulsó a sus colaboradores a bautizar su reinado en el prólogo de la obra científica más importante, las Tablas astronómicas, como «la era alfonsí»:

Et este es el reinado del Señor rey don Alfonso, que sobrepujó en saber, seso et entendimiento, ley, bondat, piedat et nobleza a todos los reyes sabios. Et por esto tovimos por bien de poner por comienzo de era ell año en que comenzó a reinar este noble rey, por cabsa que se use et manifieste esta era, ansí como se usaron et manifestaron las otras eras antes della, porque dure et quede la nombradía deste noble rey ý para siempre. Et posiemos el comienzo deste año sobre dicho

* El presente ensayo refleja posiciones asumidas en mi obra reciente El humanismo medieval y Alfonso X el Sabio. Ensayo sobre los orígenes del humanismo vernáculo, Madrid, Ediciones Polifemo, 2016. 
1252 ser comienzo desta era, et posiémosle nombre la 'era alfonsi' (Tablas astronómicas alfonsies).

No era para menos, ya que no existió en Occidente otra empresa cultural que se aproximara remotamente a la que se llevó a cabo en la corte de Alfonso X, pues como testimonia su sobrino D. Juan Manuel (h. 1282-1348): «puso en el su talante de acrescentar el saber quanto pudo, e fizo por ello mucho, assí como se falla que del rrey Tolomeo acá ningún rrey nin otro omne tanto fiziesse por ello commo él» ${ }^{1}$.

\section{HUMANISMO VERNÁCULO}

El objetivo de este ensayo no es la vastísima obra cultural alfonsí, a la cual alude el texto de su sobrino, por la cual es conocido como el Rey Sabio, sino una parcela muy particular de la misma a la cual he dedicado mi libro El humanismo medieval y Alfonso X el Sabio; cuyo tema central es la investigación de los orígenes del humanismo vernáculo. Estos orígenes, creo, se fraguaron en la corte de Alfonso $\mathrm{X}$ y fue durante su reinado cuando se manifestó por primera vez de forma clara y definitiva. Alfonso X y sus obras humanísticas por excelencia (Setenario, Siete Partidas, y las dos Estorias, especialmente la General Estoria) han sido nuestro punto de partida y de referencia, pues en ellas hemos hallado la clave para formular el concepto de humanismo alfonsí que, ya R. Menéndez Pidal, llamó «vulgar o románico» ${ }^{2}$.

Así pues, para concretar el tema de este trabajo, me voy a ocupar primeramente del contenido de los dos términos de referencia: «humanismo»y «vernáculo», expandiendo su significado a los componentes esenciales de ambos para llegar a una definición del humanismo alfonsí.

Hoy día, cuando los estudiosos de la cultura peninsular hablan de «humanismo vernáculo», por lo general, entienden una modalidad lingüística del humanismo latino italiano que, a partir de finales del siglo XV, penetró en España y se propagó en lengua castellana. Este no es el concepto de humanismo vernáculo del cual se habla aquí.

El adjetivo «vernáculo», evidentemente no necesita explicación, pues, aunque sus implicaciones socio-culturales sean muy profundas por llevar una carga de exclusividad del país en que nace y se desarrolla (vernaculus > indígena, nacional y, aquí, autóctono); con él queremos indicar el medium, o vehículo, lingüístico que usó el humanismo castellano del siglo XIII; y más concretamente se identifica con la voz «romance»y sus derivadas, «román» y «romanz»,

${ }^{1}$ Libro de la caza, G. Baist (ed.), Halle, 1880, p. 37.

${ }^{2}$ «De Alfonso [X] a los dos Juanes. Auge y culminación del didactismo (1252-1370)», en D. Catalán (ed.), Studia Hispanica in honorem R. Lapesa, I, Madrid, Cátedra-Seminario Menéndez Pidal y Editorial Gredos, 1972, pp. 63-83, p. 68. 
voces todas usadas por Alfonso X y que tienen, en primer lugar, un contenido semántico equivalente a «lengua vulgar», entendida como lengua hablada por el pueblo, en el sentido que aparece, por ejemplo, en el poeta riojano Gonzalo de Berceo (1180-1246), padre la poesía castellana, y contemporáneo de Alfonso X, cuando escribe:

\section{Quiero fer una prosa en román paladino, \\ En cual suele el pueblo fablar con so vezino; \\ Ca non so tan letrado por fer otro latino. \\ Bien valdrá, como creo, un vaso de bon vino ${ }^{3}$.}

Alfonso, al igual que Berceo, usa las voces «román», «romance», «romanz»y «paladino» (claro, público, común, fácil de entender) para indicar la lengua nativa, que es la lengua hablada, distinta y opuesta a la lengua latina, lengua culta, artificial y aprendida con el estudio, tanto en su manifestación como «lengua clásica» que como «latín vulgar». En la Estoria de España Alfonso hace decir a Urraca asediada por Sancho II en Zamora: «E con la gran saña que habie, dixo contra su hermano el Rey D. Sancho: Yo muger so, e bien sabe, que yo non lidiaré con él, mas yol faré matar a furto [a escondidas] o a paladino [públicamente] $\gg^{4}$.

Quisiera, sin embargo, aclarar que con la expresión «humanismo vernáculo» entendemos no solo el aspecto lingüístico nativo, o autóctono, de una lengua hablada, en oposición al latín vulgar y a las corrientes humanísticas latinas cultas, especialmente «chartrianas» y domésticas, del siglo anterior, sino también la tendencia a exponer los temas bajo una luz de didactismo secular y laico, antes bien que bajo la forma de unos principios religioso-morales, como se había hecho hasta ese momento. En este contexto, «vernáculo» significa también a-religioso, o a-clerical. Naturalmente, siguen existiendo en las obras alfonsíes continuas referencias a Dios, a la providencia divina y a principios religiosos cristianos que sin duda dominaban la vida del hombre medio del siglo xIII, pero, en general, se nota una tendencia a la secularización de la cultura en todas sus manifestaciones (escritura de la historia, e influjo del derecho romano en la legislación), y sobre todo en la difusión de los libri naturales de Aristóteles por los árabes en trabajos científicos, filosóficos y hasta éticos que Alfonso traduce e incorpora en sus obras con el fervor del neófito.

Las implicaciones del influjo científico-filosófico aristotélico en el pensamiento religioso alfonsí, aunque muy poco estudiadas, fueron extraordinarias, manifestándose, por ejemplo, en un nuevo

${ }^{3}$ Vida de Santo Domingo de Silos, T. Labarta (ed.), $2^{\mathrm{a}}$ ed., Madrid, Castalia, 1982, estrofa 2, p. 59.

${ }^{4}$ Estoria de España, o Primera Crónica General de España que mandó Componer Alfonso el Sabio y se continuaba bajo Sancho IV en 1289, R. Menéndez Pidal (ed.), 2 vols., Madrid, Gredos, 1955, II, Parte 4, cap. 2. 
énfasis en la consecución de la felicidad terrena, en el mundo presente, en el aquí y ahora, frente al mundo del más allá, preocupado con la salvación del alma que a veces se presenta como incierta y problemática $^{5}$. No estoy acusando a Alfonso de profesar las doctrinas del aristotelismo heterodoxo-averroísta, condenadas en Paris por el obispo Tempier en 1272, sino simplemente quiero hacer notar su tendencia hacia una visión laica de la vida que, como se sabe, fue fruto del influjo del averroísmo aristotélico que sin duda fue seguido también en España durante el reinado del Rey Sabio (como lo demuestra la obra del contemporáneo pseudo Virgilio de Córdoba ${ }^{6}$ ), y posteriormente en obras tan conocidas como el Libro de buen amor. Entre otros componentes de este humanismo vernáculo y secular pudiéramos citar también un cierto consensus social, no solo por parte de las clases dirigentes (nobleza y clero) sino también del pueblo, en la aprobación de determinados proyectos, leyes y normas de convivencia que directa o indirectamente afectaban a la comunidad.

Hechas estas aclaraciones en torno al contenido del adjetivo «vernáculo», su significado primario queda inalterado, pues se trata de un movimiento cultural autóctono que se propuso hacer uso de la lengua hablada, derivada del latín y llamada lengua vulgar o romance, en todas sus manifestaciones.

Por el contrario, el sustantivo «humanismo», y sobre todo «humanismo medieval», sí necesita una larga aclaración para que el lector se percate desde el primer momento de qué «humanismo» se trata. No es la primera vez que las voces «humanismo» $\mathrm{y}$ «humanista» se asocian con la obra cultural y la personalidad de Alfonso X. A raíz de las celebraciones del VII centenario de su muerte (1284-1984) aparecieron algunos trabajos en ese sentido. Debemos especialmente al Prof. Ángel Gómez Moreno varios estudios en los que ha presentado el panorama de los problemas que plantea la voz «humanismo» cuando se aplica a la obra del Rey Sabio. Todos estos trabajos tienen una característica en común: son valoraciones del término desde la perspectiva del humanismo latino del siglo xv; todos ellos, implícita o explícitamente, parten del postulado de que no existió un humanismo medieval. Escribe Gómez Moreno: «... si se adjudica el término humanista a Alfonso X, es siempre por extensión y analogía» ${ }^{7}$. Algo

\footnotetext{
${ }^{5}$ Se ocupa del nacimiento del espíritu laico, aunque sin referirse específicamente a Alfonso X, G. Lagarde, La naissance de l'esprit laïque au declin du Moyen Age, Paris-Louvain, 1956. Más de cerca ha tratado el problema F. Prado-Vilar, «The Gothic Anamorphic Gaze: Regarding the Worth of Others», en C. Robinson y L. Rouhi (eds.), «Under the Influence»: Questioning the Comparative in Medieval Castile, Leiden, 2005, pp. 67-100.

${ }^{6}$ Sobre Virgilio de Córdoba y su obra, véase ahora Filosofía de Virgilio de Córdoba. Aristotélico-averroista del siglo XIII, edición del texto latino y traducción castellana, introducción y notas de H. S. Martínez, León, Universidad de León, 2016.

${ }^{7}$ A. Gómez Moreno, «El humanismo de Alfonso X», en J. Montoya Martínez y A. Domínguez Rodríguez (eds.), El Scriptorium alfonsí: de los Libros de Astrología a las «Cantigas de Santa María», Madrid, Editorial Complutense, 1999, pp. 291-300, p. 294; en el mismo sentido escribe J. Fradejas Lebrero, «Alfonso X humanista», en F. Carmona y F. J. Flores (eds.), La
} 
parecido ocurre con el término «Vernacular humanism» [«humanismo vernáculo»], o «Lay humanism» [«humanismo laico»] empleado por Jeremy Lawrance y Peter Russell para los que «humanismo vernáculo» o «laico» significa: «la traducción y adaptación de las obras de los clásicos para pasatiempo de los nobles y de los lectores no profesionales de las letras ${ }^{8}$.

Por el contrario, si hablamos en nuestro ensayo de un «humanismo medieval» (latín o vernáculo), en contraposición y con independencia de la definición que se dé al «humanismo florentino» clasicista, es porque creemos que lo diferenciaron unas características propias, y porque poseyó unos valores intrínsecos propios y objetivos, y no por lo que tiene en común con el humanismo florentino, tradicionalmente considerado como el dechado de todos los humanismos.

El concepto de humanismo que predominó en muchos pensadores medievales, como los «chartrianos» y los «victorinos», y concretamente en el círculo alfonsí no fue una invención del siglo XII o del XIII, sino que había tenido ya sus precedentes en la antigüedad.

Como posible modelo ideológico, quisiera señalar un texto que siempre me ha parecido esclarecedor en el proceso histórico evolutivo del concepto de humanismo y que creo particularmente válido cuando se trata de definir el humanismo medieval en general y singularmente el de Alfonso X. Se trata de un pasaje de aquella obra miscelánea, y deliciosamente decadente, que son las Noches áticas del gran erudito y gramático latino Aulo Gelio (125-165 d. C.) $)^{9}$.

El texto de Aulo es muy significativo en el proceso de la búsqueda del significado de humanismo y creo que merece nuestra atención. Según Gelio, aquellos que han hablado el latín correctamente (más

lengua y la Literatura en tiempos de Alfonso X. Actas del Congreso Internacional. Murcia 5-10 de marzo de 1984, Murcia, Universidad de Murcia, pp. 211-218.

${ }^{8}$ «... the translation and adaptation of classical works for the entertainment of noble and unprofessional readers» («Humanism in the Iberian Peninsula», en A. Goodman y A. Mackay (eds.), The Impact of Humanism on Western Europe, Londres, Longman, 1990, 220-258, p. 222); P. Russell, «Fifteenth-Century Lay Humanism», en P. E. Russell (ed.), Spain: A Companion to Spanish Studies, London, Methuen, pp. 237-242.

${ }^{9}$ Qui verba latina fecerunt quique his probe usi sunt, «humanitatem» non id esse voluerunt quod vulgus existimat quodque a Graecis philanthropia dicitur et significat dexteritatem quandam benevolentiamque erga omnes homines promiscuam: sed «humanitatem» appellaverunt id propemodum quod Graeci paideia vocant, nos «eruditionem institutionemque in bonas artes» dicimus: quas qui sinceriter percupiunt adpetuntque, hi sunt vel maxime «humanissimi». Huius enim scientiae cura et disciplina ex universis animantibus uni homini data est idcircoque «humanitas» appellata est. (Aticae noctes, XIII, 17, J. C. Rolfe (ed.), London-New York, The Loeb Cl. Lib., vol. II, 1927, p. 456).

Ha analizado con mayor detalle este texto H. S. Martínez, «Paideia y filantropía. Sentido y alcance del humanismo alfonsí», en V. Martin (ed.), Clarines de pluma. Homenaje a Antonio Regalado, Madrid, Editorial Síntesis, Letras Universitarias, 2004, pp. 75-96. Sobre este pasaje de Gelio, véase el comentario de W. C. Kurth, «A Commentary on Book XIII of the Noctes Atticae of Aulus Gellius», Ph. D. diss., University of North Carolina at Chapel Hill, 1964, p. 362; y para la entera obra de Aulo Gelio véase ahora el erudito trabajo de L. Holford-Strevens, Aulus Gellius. An Antonine Scholar and his Achievement, Revised edition, Oxford University Press, 2003, esp. pp. 323-324. 
adelante en la misma sección incluye entre estos nada menos que a Marco Tulio Cicerón) no dieron a la palabra humanitas el mismo significado que comúnmente se cree que tiene, es decir, lo que los griegos llamaron filantropía, palabra con la cual se indicaba una actitud amistosa y benévola hacia todos los hombres sin distinción; sino que le dieron la fuerza de otra palabra griega, paideia, que es, dice Gelio, lo que nosotros llamamos «instrucción y erudición en las bellas artes». Aquellos a los que embarga un vivo deseo de poseer estas artes, concluye, son «los más humanos» (humanissimi), porque el deseo y la facultad para aprenderlas han sido concedidos únicamente a los hombres, entre todos los animales; de ahí que a su conjunto se llame humanitas [la humanidad].

Que la obra de Gelio fuese leída en clave humanística lo demuestra el elogio de Erasmo: «...Gelio en sus comentarios, más allá de los cuales nada puede ser escrito más elegante y más erudito.... ${ }^{10}$; así como la popularidad que alcanzó entre los «humanistas» españoles del siglo XVI, la época de mayor influjo del escritor latino en la literatura española ${ }^{11}$.

Según el escritor latino, por tanto, los dos significados de la palabra humanitas: como amor al hombre (filantropía), y como conocimiento de las artes liberales (paideia), son notas distintivas del ser humano, de su «humanidad», en contraposición a la «animalidad» de los brutos.

Pero hay algo más en el texto de Gelio que me interesa resaltar, por lo que diremos más adelante en relación con el humanismo alfonsí. El segundo significado (paideia) diferencia también a los hombres entre sí, haciéndoles «más humanos» en la medida de su dedicación a las letras y su perfeccionamiento en las artes liberales; paideia es el ideal humano de saber al que aspiró el humanismo alfonsí como sistema educativo de su pueblo. Gelio ilustra ulteriormente este concepto de paideia con una cita de la obra del gran pensador Marco Varrón Rerum Humanarum en la que este sabio latino llama al gran escultor Praxíteles humanior [«más humano»], según Gelio, no porque

${ }^{10}$ «...Gellius a suis commentariis, quibus nihil fieri potest neque tersius, neque eruditius...» (Adagia, chil. I, cent. 4, adag. 37).

${ }^{11}$ He aquí cómo glosó el pasaje citado el humanista Gabriel de Toro: «El vulgo comúnmente (dize Aulo Gelio) llama humanidad el amor y voluntad que un hombre tiene de ayudar y socorrer a otro, por ser de su propia naturaleza, la qual provoca y mueve que se hagan bien unos a otros; [...] latinos y oradores llamaron humanidad (según Aulio Gelio) a la doctrina y erudición de buenas letras, cuya ocupación y exercicio conviene a solo el hombre entre todos los animales, y por esso se llama humanidad y humanistas los que la estudian», (Tesoro de misericordia divina y humana, en Valencia, impresso en casa de Pedro de Huete, véndese en casa de Baltasar Simon..., 1575, fol. cxxviiv y cxxviiir, y Real Academia Española: Banco de datos (CORDE) [en línea]. Corpus diacrónico del español. <http://www.rae.es $>$ ).

Nótese que Toro añade de su cosecha la palabra «humanistas» que evidentemente no se halla en el texto latino de Gelio. Sobre la popularidad de Gelio entre los escritores castellanos del s. XVI, vid. F. García Jurado, «Aulo Gelio y la literatura española del siglo XvI: autor, texto, comentario y relectura moderna», Revista de Literatura, 74/147 (2012), pp. 31-64, p. 41. 
hubiese sido de buen natural y amable para con todos («filantropos»), que no lo fue, sino porque había sido un hombre «más culto» y «más educado» («eruditiori doctiorique») que los demás. Es evidente que, ya aquí, aparece como «más humano» el que cultiva más las artes liberales o, como diría Alfonso X más tarde, «los saberes», que es, como veremos, un concepto más amplio, pues en Alfonso incluye también las ciencias. Para Alfonso, como para Gelio, el criterio para distinguir al hombre del bruto es su capacidad de razonar y su don de la palabra, cualidades que le hacen «más hombre», es decir, «más humano»: «...ca pues que el entendimiento e la palabra estranna [separa] al omne de las otras animalias, quanto más apuesta la ha e mejor, tanto es más omne» (Partida II, IX, 30).

Antes de concluir este apartado, me parece oportuno hacer una pequeña digresión para aclarar algunos términos usados frecuentemente sin distinción de épocas ni contextos. El concepto de «humanismo», con el que a partir del siglo XIX se designa el conocido movimiento artístico-literario, al mismo tiempo que un modo de vida, nació en los comuni de Italia hacia 1300 y se desarrolló durante el Renacimiento del siglo Xv en Italia; la palabra, sin embargo, es de acuñación moderna (aparece por primera vez en Giorgio Vasari, 1511-1574). Por el contrario, la palabra «humanitas», de donde deriva el concepto, es muy antigua, como se desprende del texto de Gelio, y de otros autores, como Cicerón ${ }^{12}$. Asimismo, la palabra humanista es igualmente tardía (se halla por primera vez en una sátira de Ludovico Ariosto de 1530) y con ella se designaba a los maestros de latín y especialmente de gramática. Con anterioridad, a estos maestros de gramática se les llamaba auctoristas (así aparece en el castellano Libro de Alexan$\left.d r e^{13}\right)$ por dedicarse a exponer los «auctores» clásicos, lo mismo que se llamará juristas, canonistas, etc., a los maestros de estas ciencias. Sucesivamente, los historiadores del Humanismo del XIX aplicaron la palabra humanistas retroactivamente a todos aquellos que se habían ocupado de la enseñanza de los studia humanitatis o studia humanio$r a$, es decir, de las siete artes liberales ${ }^{14}$.

${ }^{12}$ De oratore, I, 71; II, 72 y Defensa del poeta Arquías, A. D’Ors (ed.), Madrid, 1940, pp. 23-25.

Cuentan los actoristas, que dizen muchas befas, que fue una serpiente que avié siet cabeças; quando le tollién una, siet le naçién espesas, semeja que es esto las nuevas mesmas essas. (copla 1197)

Los «auctores» en los que aparece la historia de la Hidra son: Hesiodoro, Teogonía; Virgilio, Eneida; y Ovidio, Metamorfosis. Todos ellos comentados por los «actoristas», a los que alude el poeta.

${ }^{14}$ Cfr. G. Billanovich, Auctorista, humanista, orator, Bellaterra, Universidad Autónoma de Barcelona, 1989; A. Campana, "The Origin of the Word "humanist"», Journal of the Warburg and Courtauld Institutes, IX (1946), pp. 60-73. Sobre los aspectos ciceronianos del humanismo de todos los tiempos, cfr. A. Fontán, Artes ad humanitatem. Ideales del hombre y de la cultura en tiempos de Cicerón, Pamplona, Publicaciones del Estudio General de Navarra, 1957. 


\section{HUMANISMO ALFONSÍ Y HUMANISMO CLASICISTA}

Teniendo presentes estos antecedentes sobre el uso de los términos «humanismo» y «humanista» durante el Renacimiento italiano, cuando se trata de contrastarlos con los usados por Gelio, filantropía y paideia, nos hallamos ante carriles paralelos que no se intersectarán hasta mucho más tarde. Sin duda los términos usados por Gelio son aplicables al concepto de humanismo profesado por muchas de las grandes figuras de las letras y las ciencias del siglo xv; pero no siempre han sido tenidos en cuenta por los estudiosos a la hora de definir el concepto de «humanismo»y «humanista». De hecho, en la historiografía del pensamiento renacentista cuando se habla de «humanismo», así como de su expresión correlativa «humanidades», tradicionalmente, ha prevalecido el segundo significado del que habla Aulo Gelio (paideia), con el que se pretende expresar, ante todo, el movimiento de retorno a la literatura greco-latina clásica, mediante el cultivo de lo que los latinos llamaron humaniores litterae o studia humanitatis que correspondían a las siete artes liberales (artes libero dignae). Este concepto de «humanismo», latinizante-helenizante, que aparece en Europa con Francesco Petrarca (1304-1374) y se desarrolla brillantemente en Italia durante dos siglos (1350-1550), cobra paulatinamente un sentido aún más restringido y técnico, si se quiere. De hecho, las «humanidades» promovidas por los primeros «humanistas» italianos, casi todos ellos florentinos, no abarcaban el estudio y el cultivo de todas las artes liberales de la antigüedad y, por supuesto, ninguna de las ciencias humanas (filantropía) o de la naturaleza a las que hace alusión el texto de Aulo Gelio, sino solo aquellas disciplinas propias del trivium medieval; y, aún dentro de estas, preponderaban la gramática y la retórica sobre la dialéctica. El mismo Nebrija, introductor del humanismo clasicista en España, «no quiso más timbre de gloria que el título de grammaticus» ${ }^{15}$.

Sucesivamente, y como resultado de la reacción contra la Escolástica medieval, el humanismo renacentista mantuvo un extraordinario desprecio por la Filosofía, que sus más distinguidos representantes no acertaron a comprender, lo cual no hizo más que contribuir a desvirtuar aún más el concepto amplio y armónico de humanismo que había sido aceptado ya por los estudiosos desde el siglo XIII. Lorenzo Valla (1407-1457), máximo representante del humanismo clasicista, afirmaba: «En verdad, la filosofía, como un soldado o un tribuno, se halla bajo las órdenes de la oratoria que, como dice un gran autor trágico, es la reina» ${ }^{16}$.

\footnotetext{
${ }^{15}$ Francisco Rico, Nebrija frente a los bárbaros. El canon de gramáticos nefastos en las polémicas del humanismo, Salamanca, Universidad de Salamanca, 1978, p. 120, 73 y ss.

${ }^{16}$ «Siquidem philosophia velut miles aut tribunus sub imperatrice oratione et ut magnus quidam tragicus appellat regina» (De vero falsoque bono, Matistella de Panizza Lorch (ed.), Bari, Adriatica, p. 70). Sobre este tema pueden consultarse Jerrold E. Seigel, Rhetoric
} 
La afirmación de Lorenzo Valla contrasta con la visión de la filosofía y las siete artes liberales que se tenía en el siglo XII, como se ilustra espléndidamente en el Hortus delitiarum, obra de la monja Herrada de Hohenbug, terminada en 1280; donde se afirma: «De la Filosofía fluyen las siete fuentes de la sabiduría que se llaman Artes Liberales. El Espíritu Santo fue el inventor de estas Siete Artes Liberales que son: gramática, retórica dialéctica, música, aritmética, geometría y astronomía» ${ }^{17}$. Esta visión de la Filosofía como el centro y la fuente de la cual fluyen las Siete Artes Liberales es compartida plenamente por Alfonso X.

Para Alfonso la filosofía es la ciencia suprema, «es el saber que encierra todos los otros saberes». Alfonso usa la palabra en sus dos acepciones principales. La primera, para indicar lo que etimológicamente significa: amor de la sabiduría; y la segunda, como disciplina que se ocupa de las realidades mundanas, así como de aquellas que están más allá de la experiencia física, es decir, la metafisica, o filosofía primera, según la nomenclatura aristotélica. En el estudio de las siete artes liberales y su relación con la filosofía, el Rey Sabio se sirve de esta segunda acepción con una finalidad muy concreta, unificar la totalidad de las ciencias bajo un único concepto:

Et los gentiles, que se trauaiauan de dezir las cosas encubiertamientre et por tales semeianças como aquí oydes, dizen que por la philosophia, que es el saber que encierra todos los otros saberes, llamaron huerta; et por las siete artes del triuio e del quadruuio dixieron áruoles que lleuauan ramas, e mançanas, e fruta, e foias que eran doro, et estauan en aquella huerta como las artes en la philosophia ( $G E$, II, 1, 284a).

Y hablando específicamente de la metafísica dice:

El más ondrado de los otros saberes que sin estos siete [h]ay, e aun destos et de todos, es, la methafísica, que quiere dezir tanto como sobre natura, porque muestra connoscer las cosas celestiales, que son sobre natura, assí como es Dios, e los ángeles e las almas (GE, I, 196b).

Alfonso parece estar aquí identificando la metafísica con la teología. Sin embargo, en el Setenario la había descrito como la «más noble e más ssotil que todas ellas [artes liberales] porque por esta

and philosophy in Renaissance Humanism from Petrarch to Valla, Princeton, 1988; y HannaBarbara Gerl, Rhetorik als Philosophie: Lorenzo Valla, Munich, 1974 (diss).

${ }^{17}$ «Septem fontes sapientiae fluunt de philosophia que dicuntur liberales artes. Spiritus Sanctus inventor est Septem liberalium Artium que sunt grammatica, rethorica, dialectica, musica, arithmetica, geometria, astronomía». Este texto se lee a derecha e izquierda del trono de Filosofía (vid. ilustración 1). 


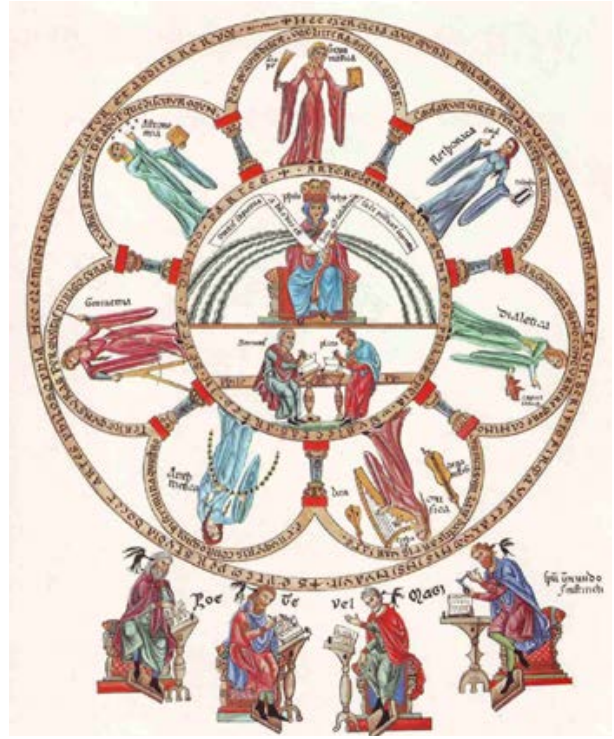

Fig. 1. De la Filosofía fluyen las siete fuentes de la sabiduría que son las Siete Artes Liberales, según Herrada de Hohenburg, Hortus delitiarum (1180).

se conoscen todas las cosas ssegunt ssu natura ${ }^{18}$. Es evidente que cuando escribe estas palabras, poniendo el énfasis en el conocimiento de «todas las cosas ssegunt ssu natura», está pensando en la obra filosófica por excelencia, la Metafisica de Aristóteles, de la cual hizo amplio uso tanto en las dos Estorias como en las Partidas.

Siguiendo el gran influjo que la filosofía aristotélica estaba teniendo en sus días, cuando el saber humanístico del pasado se estaba derrumbando bajo la presión de la lógica, por un lado, y de los libri naturales, por otro, Alfonso, siguiendo la metáfora ovidiana, concibe las siete artes liberales como ramas, manzanas, fruta y hojas de oro, que crecen en la huerta de la filosofía. En el fondo de esta actitud poético-alegórica, podemos ver el esfuerzo de un humanista que trata de adaptar, para salvarlo, el saber tradicional a las nuevas realidades y exigencias intelectuales del presente, teniendo en cuenta aquellas corrientes científico-filosóficas que amenazaban acabar con las estructuras tradicionales del saber.

El conflicto entre la filosofía, como ciencia independiente, y el humanismo clasicista, aferrado a las artes liberales, especialmente a la retórica, se prolongó hasta muy entrado el Renacimiento, llevando la controversia a un terreno mucho más amplio que fue la confrontación entre humanistas y escolásticos ${ }^{19}$. En el fondo, creo que este conflicto fue la verdadera causa de la famosa querella entre Alfonso de Cartagena (1384-1456), obispo de Burgos e intelectual de punta de la corte de Juan II, y el gran humanista Leonardo Bruni (h. 13701444) sobre la traducción de la Ética nicomáquea que este había llevado a cabo directamente del griego. Cartagena sostenía que para leer las obras aristotélicas y, por tanto, para traducirlas, no bastaba

${ }^{18}$ Setenario, K. Vanderford (ed.), Buenos Aires, 1945, reimpresión Barcelona, Crítica, 1984 , p. 36 y 38.

${ }^{19}$ M. I. Lafuente, «La postura filosófica de un humanista español: lógica, dialéctica, retórica, aristotelismo y platonismo en la «disputa contra Aristóteles» de Alonso de Herrera», en J. M. Maestre, J. P. Barea y L. Charlo Brea (coords.), Humanismo y pervivencia del mundo clásico: homenaje al profesor Antonio Prieto, vol. 1, 2008 (Literatura castellana y mundo clásico), pp. 2705-2716. 
con dominar la lengua griega y la retórica latina, sino que hacía falta también saber filosofía. El sabio obispo y fino teólogo moralista no se metía con la incuestionable habilidad lingüístico-retórica de Bruni, sino con la incongruencia de emplear una terminología estoica, extraída de las obras de Cicerón, para traducir el pensamiento ético de Aristóteles, el cual gozaba ya de una terminología comúnmente aceptada desde el siglo XIII. La nueva técnica ciceroniana empleada por Bruni era para Cartagena motivo suficiente para poner en duda la fidelidad de su traducción. Naturalmente la aserción del obispo, que ponía en tela de juicio el conocimiento de Bruni del pensamiento aristotélico, ha hecho levantar el grito al cielo a los italianistas de todos los tiempos, sirviendo así a la causa de los humanistas modernos y contemporáneos que han acusado a Cartagena de mantener una actitud medieval y antihumanística.

...lo cierto es, escribe María Morrás, que entre los estudiosos de la cultura italiana del Quattrocento subsiste una imagen que, simplificando algo, podríamos decir que consiste en presentar a Bruni como paladín del Humanismo y el concepto moderno de la traducción y a Cartagena como obcecado y cerril representante del pasado medieval... Así, es posible percibir en la polémica entre Leonardo y Alonso la inquina profesional entre juristas [Catagena] y filólogos [Bruni], la rivalidad nacionalista entre italianos y españoles (con latinos y godos al fondo), el choque entre quien desea romper con el pasado y quien cree necesario mantener un diálogo con él, la susceptibilidad del traductor que se siente acusado de plagio o la competencia por lograr autoridad intelectual y prestigio ante otras gentes del saber ${ }^{20}$.

El mensaje que quisiera extraer de la célebre polémica es que, desde la perspectiva histórica, el concepto de humanismo propuesto por Aulo Gelio (a la vez filantrópico y paideico), se ha visto desde el primer momento en conflicto con el humanismo latino-clasicista, el cual se presenta como un movimiento de miras muy estrechas, olvidando el significado filántropico y relegando el paideico exclusivamente a las artes del trivium, y concretamente a la gramática y la retórica, cuando en partes de Europa se iba ya por otros derroteros. Esto no era progreso, del que tanto se pavoneaban los grandes humanistas del siglo XV, sino retroceso; «renacer» $\mathrm{y}$ «renacimiento»,

${ }^{20}$ «El debate entre Leonardo Bruni y Alonso de Cartagena: las razones de una polémica», Quaderns. Revista de traducció, 7 (2002), pp. 33-57, p. 37 y 39. La autora apunta también al hecho de que recientemente algunos estudiosos, como C. Vasoli, han cortado puntas estridentes al debate. Cfr. C. Vasoli, «Il debatttito tra Leonardo Bruni e Pedro García de Cartagena: Due culture a confronto», Miscellanea umanistico-catalana, Barcelona, 1991, pp. 3-28; Id., «L'umanesimo e la scolastica», en C. Leonardi (ed.), Gli umanesimi medievali. Atti del II Congresso dell' "Internationales Mittellateinerkomitee», Florencia, 1998, pp. 781-795; y P. Viti, «Leonardo Bruni e le polemiche antiumanistiche», en C. Leonardi (ed.), op. cit., pp. 795-805. 
en este contexto, son conceptos que enfatizan la necesidad de volver hacia atrás, a aquellas posiciones académicas medievales centroeuropeas, anteriores a la llegada de la filosofía aristotélica, en las que dominaban las artes de trivium $^{21}$.

Como he señalado en otro lugar, existieron enormes diferencias entre la educación que se impartía en la Europa cristiana y la impartida entre los musulmanes de al-Ándalus, donde predominaba el quadrivium, con las ciencias de la naturaleza a la cabeza, así como el método científico para conocerlas mediante «la investigación y la observación», sirviéndose como instrumentos para su estudio de las obras de Aritóteles, entre las que hallamos la Física y el De coelo et mundo, obras que no llegarán a manos cristianas hasta más de dos siglos después en traducciones latinas del árabe ${ }^{22}$.

No obstante, estas enormes limitaciones, el humanismo latinoflorentino, en su impulso inicial, fue un movimiento intelectual lanzado por un grupo de ingenios selectos al margen de las instituciones universitarias, cuyos participantes en determinados instantes se agruparon en academias exclusivas, amparados por generosos mecenas. Protectores y protegidos fueron los responsables de la creación de un nuevo clima espiritual en el que se promovía el cultivo y la pasión por los clásicos, resucitando sus ideas y sus formas literarias y hasta el mismo ideal educativo de la Antigüedad. De ese clima espiritual son todos ellos muy conscientes; a todos les alienta la idea de que está apareciendo una nueva aurora en el espíritu humano: «Este es un siglo de oro, escribe Marsilio Ficino (1433-1499), el que ha puesto nuevamente a la luz las disciplinas liberales casi extinguidas, la gramática, la poesía, la elocuencia, la pintura, la arquitectura, la escultura, la música, el arte de cantar con la antigua lira de Orfeo; y todo esto en Florencia» ${ }^{23}$. Se ha dicho ya muchas veces que San Ambrosio (333-397), Alcuino (735-804) y Juan de Salisbury (h. 1110/1120-1180), los tres representantes más distinguidos de otras tantas manifestaciones del humanismo anterior al florentino, también habían leído el De officiis de Cicerón, pero no les decía lo mismo que a Poggio Bracciolini (1380-1459), a Francesco Filelfo (1398-1481) o a Lorenzo Valla (1407-1457). El espíritu de aquellos, se dice, era «medieval»; el de estos, «humanista». Disyuntiva que, a la luz de lo

${ }^{21}$ Dicho con palabras de María Morrás, la forma de proceder de Bruni:

...tiene un algo de anacronismo lingüístico al hacer hablar a Aristóteles como si fuera

Cicerón, creando así un Aristóteles cortado a medida del humanismo; es como si hoy nos empeñáramos en traducir a santo Tomás de Aquino empleando el vocabulario y el estilo de Ortega y Gasset. (art. cit., p. 49).

${ }^{22}$ Sobre la enseñanza en al-Ándalus, hemos reproducido el extraordinario testimonio que nos proporciona el almeriense Sa'id al-Andalusí (1029-1070), historiador y filósofo de la ciencia, al hacer el elogio del célebre pensador y político judío Abul Fad'l Hasdai (1046-1100) antes de su conversión al islam en H. S. Martínez, El humanismo medieval, pp. 75-77, y pp. 56-57, nota 21.

${ }^{23}$ Epistolae, 1. 12, fol. 229b-230a. 
que hemos venido diciendo, no parece muy acertada, ya que también los medievales fueron humanistas, aunque, claro, no a la florentina.

Dentro de este movimiento intelectual florentino, caracterizado por su admiración por los clásicos, eran «humanistas» (según Vasari), ante todo, los gramáticos y filólogos que, dotados de un profundo conocimiento del latín, y más tarde del griego, podían degustar las incomparables bellezas de las literaturas clásicas en sus textos originales. Este concepto de «humanismo», a pesar de que desde una perspectiva más amplia de la historiografía literaria no llegase a ocupar más que una mínima parte del mundo cultural del siglo $\mathrm{XV}$, por las razones apuntadas, fue rodeado ya desde el primer momento de un aura de exquisitez y exclusividad intelectual tal, que ha dominado las letras europeas durante más de seis siglos y probablemente las seguirá dominando in aevum. Todavía hoy, como aludía más arriba, no hemos podido sacudirnos de encima tan estrecha concepción de humanismo, a pesar de reacciones tan negativas como la de Philippe Monnier, que lo definió: «puerile, longue et maladroite copie de l'Antiquité»»" ${ }^{24}$ o la de Ortega y Gasset que lo llamaba la «dictadura de los gramáticos», añadiendo: «El hecho es de sobra grotesco, pero está ahí sin remedio y 'ahí' quiere decir dentro de nosotros, los occidentales, que no hemos acabado todavía de digerir y, merced a ello, de eliminar nuestro abolengo humanístico, toxina aún operante en las entrañas de la vida europea $\rangle^{25}$. Ortega no tenía por qué irritarse tanto; si hubiese tenido la preocupación de volver sus ojos atrás, como lo hizo en otras ocasiones, para echar un vistazo al suelo patrio, tal vez habría dado con una linea de pensamiento autóctono capaz de contrarrestar aquella «dictadura». Esa línea de pensamiento que, como hemos venido diciendo, puede ya descubrirse en el mismo Aulo Gelio, fue continuada por el mayor humanista de la España del siglo XIII, Alfonso X, cuyo ideal fue el conocimiento exacto y completo de la realidad, del individuo y de la sociedad, a la cual dotó de estructuras más justas y apropiadas para el desarrollo humano integral.

Los promotores del humanismo florentino, conocido como humanismo literario, latino o clasicista, identificaron su tarea con la más humana («humanior») de las actividades, considerando a sus

${ }^{24}$ Le Quattrocento, Essai sur l'histoire littéraire du XV siècle italien, Paris, 1920, vol. 2, I, p. 212. Treinta años más tarde, su connacional A. Pauphilet escribía del periodo medieval: «Cette époque, malgré les idées reçues, dépend plus qu'aucune autre de l'Antiquité, ne se définit que par rapport à l'Antiquité... Problème capital, et je dirais le problème unique du Moyen Age. Car à chaque siècle, à chaque génération, de Sidoine Apollinaire a Guillaume Budé, le Moyen Age se définit par le degré ou il est de compréhension de l'Antiquité» (Le Legs du Moyen Age, 1950, pp. 92 y 106).

${ }^{25}$ Aula Nueva. Instituto de Humanidades, Madrid, 1948, p. 3. Cuando escribe Ortega, la polémica del Humanismo llevaba en curso varios siglos. Cfr. N. Round, «Renaissance culture and its opponents in 15th-Century Castile», Modern Languages Review, 57 (1962), pp. 204 215; y P. E. Russell, «Las armas contra las letras» en su libro Temas de «La Celestina», pp. 207-239; H. Méchoulan, L'Antihumanisme de Juan Ginés de Sepúlveda: Étude critique du «Democrates Alter», Paris, Mouton, 1974. Cfr. H. S. Martínez, «Paideia y filantropía», pp. 2-3. 
inmediatos predecesores en este campo, es decir, los medievales, como enemigos del saber, de carecer de la sensibilidad estética para percibir las cualidades literarias de los clásicos, de destruir su estilo y en general de haber abandonado el estudio de las artes (o studia humanitatis) para ocuparse exclusivamente de la teología, del derecho canónico, y de la lógica.

Este escenario cultural, como se expone en mi obra, es una versión tergiversada, incompleta y hasta errónea de lo que fue el humanismo medieval. El mismo Ángel Gómez Moreno reconoce:

una lectura libre de prejuicios de los grandes abanderados del Humanismo nos obliga a revisar una idea heredada extendida hasta el extremo: la idea de que la Edad Media buscaba en los clásicos normas morales mientras el Renacimiento solo atendía a su valor artístico. Esta afirmación es solo cierta en parte y, en cualquier caso, nos pide a voces que se la matice debidamente ${ }^{26}$.

Mi libro sobre el humanismo alfonsí es una larga matización de dicha afirmación, fundándome en la evidencia que se desprende de textos tan dispares como la «Carta a los estudiosos franceses» del judío converso aragonés Pedro Alfonso ( $\dagger$ h. 1130), o las críticas cáusticas de estudiosos ingleses, como Daniel de Morley (h. 1140h. 1210), Adelardo de Bath (h. 1080-h. 1152), y del mismo Juan de Salisbury (1120-1180), considerado el mayor humanista del siglo XII.

Para enredar más las cosas, un grupo de críticos centroeuropeos, científicos y «humanistas», del siglo XIX (Michelet, Burckhard, Voigt), lanzaron un nuevo concepto de humanismo, el científico, con el que pretendían explicar también el renacimiento de las ciencias de la naturaleza en coincidencia con las más altas manifestaciones del humanismo clasicista. Según estos estudiosos, la ocupación principal de toda ciencia es el estudio coherente de la naturaleza, incluyendo la del hombre, promoviendo los intereses de la humanidad mediante el saber científico que nos lleva a penetrar los secretos de la naturaleza humana y del cosmos, mediante el estudio racional del hombre y su entorno. Esta visión del humanismo tiende a eliminar todo lo que no es objeto de experimento o perceptible por los cinco sentidos, de tal manera que excluye, o por lo menos a reduce, el estudio del sobrenatural en la vida del hombre. Naturalmente, para los que sostienen esta visión del humanismo, su enemigo natural es la teología como disciplina opuesta a las ciencias, por pretender ordenar la vida humana a partir de unas verdades reveladas, interpretadas por una autoridad suprema e infalible, e impuestas por una organización jerárquica, claramente en conflicto con las ciencias de la naturaleza y la razón humana. Para estos pensadores, la Edad Media es el epítome

${ }^{26}$ España y la Italia de los humanistas, Madrid, Gredos, 1994, pp. 87-88. 
del oscurantismo, la época diametralmente opuesta al humanismo racional y progresista. Este humanismo naturalista, científico y filosófico, secular y laico, según la crítica histórica de la edad de oro y del positivismo laico del siglo XIX pretende también anclar sus orígenes en coincidencia y como resultado del humanismo florentino del siglo $\mathrm{xV}$, olvidando que este no fue ni laico ni científico ${ }^{27}$.

Esta iniciativa dio una nueva dimensión y un nuevo y mayor prestigio al humanismo literario-clasicista, al dotarlo de una calidad que, como se dijo, no había tenido nunca, es decir, la de ser también un humanismo científico. En el proceso (estamos en la época de la Ilustración) los dichos «críticos» crearon una inquina tal contra todo lo medieval que ha resultado imposible durante más de doscientos años hablar de humanismo medieval y, por supuesto, absurdo insinuar que existiese un humanismo vernáculo en el siglo XIII.

No cabe duda de que una buena parte de los hombres cultos del siglo XV dirigieron también sus esfuerzos al estudio de la naturaleza humana y del mundo en que el hombre habita. Esta actitud, como había sucedido ya en el siglo XIII, no estaba exenta de peligros en el campo religioso; ya que ha sido precisamente la dimensión científico-naturalista del humanismo, con su deseo de hacer resaltar la contraposición entre la visión sobrenatural que del hombre se tenía en la Edad Media y la naturalista pagana que caracteriza al hombre culto del Renacimiento, la que a veces a dado al humanismo del siglo $\mathrm{XV}$, y sucesivamente al de todos los tiempos, su pésima reputación en determinados círculos religiosos. La causa de esta reputación negativa tiene sus antecedentes inmediatos precisamente en las tergiversaciones y la interpretación unidimensional del humanismo florentino por parte de los positivistas del siglo XIX. Hay que reconocer que entre los humanistas del pasado (incluyendo los medievales), como en todos los movimientos intelectuales, ha habido ortodoxos y heterodoxos; pero no debemos asumir, como punto de partida, que el humanismo, tanto en su vertiente literaria como científica, sea sinónimo de heterodoxia y paganismo, aunque la conjunción de ambos conceptos, humanismo científico y humanismo literario, por las causas apuntadas, haya llegado a trasmitir a la posteridad una visión tremendamente negativa de cualquier proposición que de alguna manera adelante la idea de un humanismo medieval, especialmente si en ella se hace referencia a un humanismo vernáculo que a todas luces parecería la negación de la idea misma de humanismo, concebido exclusivamente como latino-florentino-clasicista o como científico.

Rebatir estas posiciones, aun hoy día, es dar palos de ciego. Pero creo que merece la pena intentarlo, aunque tenga que repetir algunos conceptos sabidos, recordando, en primer lugar, que las cosas

\footnotetext{
${ }^{27}$ Analiza el proceso intelectual que ha llevado a la creación, o «invención», de la imagen negativa de la Edad Media, como el epítome del oscurantismo, J. Heers, La invención de la Edad Media, Barcelona, Crítica, 1995.
} 
no acontecieron exactamente como nos las han presentado los críticos del siglo XIX, inventores del mito de un humanismo clasicista, fijándose solo en un puñado de ingenios selectos que, en su autosuficiencia, estaban convencidos de que solo la lengua latina poseía la capacidad de trasmitir la cultura. Fue esta una idea que se cuestionó desde el primer momento por aquellos que hoy reconocemos como los padres del Humanismo, latino y vernáculo; pues sabemos que antes de que naciese la idea de re-nacimiento como vuelta al pasado latino, circulaban ya obras latinas en las lenguas vulgares cuyo objeto era poner al alcance de los que desconocían el latín los textos de los clásicos, dándoles así también a ellos acceso al saber del pasado.

En este contexto histórico-cultural, hay que colocar la obra vernácula de Alfonso X, el cual no fue el primero en usar el vernáculo para escribir sus obras. Existía ya una rica literatura en lengua francesa, así como varios volgarizzamenti en los distintos dialectos de Italia ${ }^{28}$; pero todas estas obras fueron esfuerzos personales de individuos que trabajaban en solitario y sus esfuerzos no tuvieron el sello de aprobación de las instituciones o de una autoridad que convirtiese aquella lengua en la cual estaban escritas en la lengua de cultura de la comunidad que las produjo, como sucedió con el castellano ${ }^{29}$.

${ }^{28} \mathrm{Cfr}$. A. Fourrier, L’humanisme médiéval dans les litératures romanes du XIII au XIV siècles, Paris, 1964; C. Segre, Volgarizzamenti del Due e Trecento, Unione Tipografico-Editore Torinese, 1953; Id. Lingua, stile e società. Studi sulla storia della prosa italiana, Milano, Feltrinelli, 1963, pp. 49-78; G. Folena, «"Volgarizzare" e "tradurre": idea e terminologia della traduzione dal medioevo italiano e romanzo all'umanesimo europeo», La traduzione: saggi e studi, Trieste, Lint, 1973, pp. 57-120; y sobre todo B. Guthmüller, Die «volgarizzamenti», in Grundriss der romanischen Literaturen des Mittelalters, hrsg. von H. R. Jauss y E. Köhler, Heidelberg, Winter, 1968-1993, 11 vols., vol. 10/2 (Die italienische Literatur im Zeitalter Dantes und am Übergang vom Mittelalter zur Renaissance. Die Literatur bis zur Renaissance, dir. A. Buck, 1989, pp. 201-254).

${ }^{29}$ Naturalmente no han faltado estudiosos que han atribuido a manifestaciones vernáculas locales valor de «lengua nacional». Cfr. S. Santangelo, Il siciliano lingua nazionale nel secolo XIII, Catania, Dott. Crisafulli, 1948; Id., «La scuola poetica siciliana del secolo XIII», Studi medievali, 17 (1951); Id., «Il volgare illustre e la poesia siciliana del secolo XIII», en Atti della R. Accademia di Scienze, Lettere e Belle Arti di Palermo, s. III, vol. XIII, 1926; pero véase el ensayo de G. Gentile, Il tramonto della cultura siciliana, Bologna, Zanichelli, 1919. En Francia esto no aconteció hasta finales del siglo XIV, cuando, según el parecer de los estudiosos, la lengua francesa fue considerada como lengua de cultura en ocasión del movimiento de las traducciones de los clásicos. Cfr. S. Lusignan, Parler vulgairement: les intellectuels et la langue française aux XIIF et XIV siècles, Paris, Vrin y Montreal, University of Montreal Press, 1986, pp. 129-171: «Le mouvement des traductions au XIV siècle et la définition du français comme langue savante»; J. Monfrin, «La connaissance de l'Antiquité et le problème de l'humanisme en langue vulgaire dans la France du Xve siècle», en G. Verbeke y J. Ijsewijn (eds.), The Late Middle Ages and the Dawn of Humanism outside Italy, Louvain-The Hague, 1972, pp. 131170; D. Norberg, "À quelle époque a-t-on cessé de parler latin en Gaule?», Annales (Économies, Sociétés, Civilisations), 21 (1966), pp. 346-356. Para el resto de Europa, véase R. Copeland, Rhetoric, Hermeneutics, and Translation in the Middle Ages. Academic Traditions and Vernacular Texts, Cambridge, Cambridge University Press, 1991, pp. 96-97, notas 19-20; pp. 103-107, notas 39-50, y p. 180. Como ha ilustrado espléndidamente esta estudiosa, el lanzamiento de las lenguas vulgares como medio para difundir la cultura clásica tradicional estaba en la Romania en su infancia cuando llega Alfonso X al trono. 
Bajo Alfonso X, el vernáculo se convirtió no solo en la lengua oficial del reino, sino también en la lengua en la que se reescribió el saber del pasado.

La vulgarización, escribe Domingo Ynduráin, que, aunque tenga caracteres específicos en España, se da en todas partes, incluida la renacentista y humanista Italia, apesar de que sus ingenios, atenazados por la prepotencia de los humanistas exquisitos, estuvieran en Babia y a verlas venir ${ }^{30}$.

Esta afirmación necesita ser matizada, ya que en Italia, los que son considerados padres del Humanismo, apesar de su obsesión con la superioridad de la lengua de los clásicos latinos y el menosprecio del vernáculo, sin embargo, fueron también los primeros en valorar el vernáculo, actitud frecuentemente ignorada por los grandes humanistas de la segunda generación, los renacentistas ${ }^{31}$.

Dante (1265-1321), que tenía unos 19 años cuando murió Alfonso $\mathrm{X}$, no obstante que en el Convivio mantuviese la superioridad del latín sobre el vulgar, en el De vulgari eloquentia, para probar que el italiano/toscano era una lengua heredera de Roma, afirmó: «la lengua vulgar es más noble que la latina» [«nobilior est vulgaris»], anticipándose así a su tiempo, al propugnar el uso del romance y el abandono del latín para las obras literarias y hasta filosóficas ${ }^{32}$.

Petrarca (1304-1374), considerado por muchas razones el verdadero padre del humanismo clasicista, sin embargo, y apesar de que, como Dante, escribía indistintamente en ambas lenguas, no aceptó nunca esta proposición ${ }^{33}$.

${ }^{30}$ Domingo Ynduráin, El fin del humanismo tradicional, J. Gómez (ed.), Huelva, Universidad de Huelva, 2014, p. 83.

${ }^{31}$ Dante, por ejemplo, escribe en Il Convivio:

... lo latino è perpetuo e non corruttibile, e lo volgare è non stabile e corruttibile. Onde vedemo ne le scritture antiche de le comedie e tragedie latine, che non si possono transmuttare, quello medesimo che oggi avemo; che non avviene del volgare, lo quale a piacimento si trasmuta (Busnelli e Vandelli (eds.), I.5, p. 33)

Discute esta común creencia entre los humanistas de que el latín era inmutable e incorruptible mientras que las lenguas vulgares lo eran, R. Copeland, Rhetoric, pp. 104-105, 251, notas $49-50$.

${ }^{32}$ Cfr. Cecil Grayson, «Nobilior est vulgaris: Latino e volgare nel pensiero di Dante», Cinque saggi su Dante, Bologna, 1972, pp. 1-31.

${ }^{33}$ Recientemente R. G. Witt, sobre las huellas de P. O. Kristeller, ha sostenido que el humanismo nació en Francia a mediados del siglo XIII, siendo Petrarca un humanista de tercera generación cuyo rol fue cristianizar un movimiento literario de los siglos XII y XIII esencialmente pagano. Witt, sin embargo, ve el humanismo medieval como un preámbulo al florentino clasicista y no como un movimiento con sus propias características (In the footsteps of the ancients: The Origins of Humanism from Lovato to Bruni, Leiden-Boston, Brill, 2000); y sobre todo en Id., «Medieval 'Ars Dictaminis' and the Biginnings of Humanism: a New Construction of the Problem», Renaissance Quarterly, 35/1 (1982), pp. 1-35. Sobre el tema véanse B. L. Ulman, «Some Aspects of the Origin of Italian Humanism», Studies in the Italian Renaissance, Storia e letteratura, rev. ed., 51, Roma, 1973, p. 138 y ss.; y F. Simone, «Medieval French 
El tercero de los tres grandes, Giovanni Boccaccio (1313-1375), exponiendo las razones por las que Dante escribió una obra tan grande como la Divina Commedia en lengua vulgar, escribe:

La primera de ellas, es que lo hizo para mayor utilidad de sus conciudadanos [florentinos] y los demás italianos; sabiendo que si hubiera escrito métricamente en latín, como otros poetas pasados, solo habría sido útil a los hombres de letras ${ }^{34}$.

Y finalmente, el gran humanista Leonardo Bruni, ya en pleno Renacimiento, en la Vita di Dante, fue aún más allá, llegando a comparar, mirabile dictu!, la lengua vulgar escrita con la lengua latina: «El escribir en estilo culto o vulgar no tiene nada que ver con la lengua, ni hay diferencia alguna entre escribir en griego o en latín; cada lengua tiene su perfección y su sonido y su decir limado y científico» ${ }^{35}$.

Es evidente que estos prohombres de las letras se dieron cuenta desde el primer momento de la utilidad de escribir en lengua vulgar, de la cual hablaba Boccaccio; un siglo antes ya había caído en la cuenta Alfonso X.

Existió, pues, una preocupación entre los padres del humanismo italiano por la revalorización de la lengua vernácula, aunque los que les siguieron, infatuados con la superioridad del latín, tardaron mucho en reconocerlo. Por otro lado, ellos mismos, sentimentalmente aferrados al latín, nunca pensaron en proclamar el vulgar lengua de cultura. Esta proclamación tuvo lugar durante el reinado de Alfonso $\mathrm{X}$ donde, tras la unificación del territorio conquistado por su padre, se dieron las condiciones sociales propicias y la necesidad de cobijar bajo una misma lengua culturas y religiones diferentes.

La actividad cultural de la corte alfonsí, conocida entre los intelectuales italianos a raíz de la visita histórica de Brunetto Latini a Sevilla en 1260 , ha llevado a algunos estudiosos a preguntarse: ¿existió alguna relación de dependencia entre los padres del humanismo italiano y Alfonso X? La estudiosa Julia Bolton Holloway, en un estudio pionero sobre esta posible relación, escribe: «Sospecho con buen fundamento que la decisión de Alfonso el Sabio de enfatizar la escritura vernácula, poco común en este periodo, influyó en la decisión de Brunetto Latini de hacer otro tanto, y a su vez, en Dante» ${ }^{36}$. Asimis-

Culture and Italian Humanism», The French Renaissance, H. Gaston Hall (trans.), London, 1969, pp. 279-290.

${ }^{34}$ Giovanni Boccaccio, Vida de Dante, Intr., trad. y notas de Carlos Alvar, Madrid, Alianza, 1993, p. 109.

${ }^{35}$ «Lo scrivere in istile letterato o volgare non ha a fare al fatto, nè altra diferenza è, se non come scrivere in greco od in latino; ciascuna lingua ha sua perfezione e suo suono e suo parlare limato e scientifico» (Hans Baron (ed.), Leipzig, 1928).

${ }^{36}$ «I strongly suspect that Alfonso el Sabio's decision to stress vernacular writing, which was unusual in this period, influenced Latini's similar choice and, in turn, Dante's» («Alfonso el Sabio, Brunetto Latini and Dante Alighieri», Thought, 60/239 (dic. 1985), p. 480); Id., «The 
mo, otro grande especialista en la lengua alfonsí, H. -J. Niederehe, cree que las ideas expuestas por Dante en el De vulgari eloquentia sobre la lengua vulgar fueron anticipadas por Alfonso $\mathrm{X}^{37}$.

Es, pues, innegable que mucho antes de que naciese el humanismo florentino clasicista, existió un humanismo literario y científico que tuvo ya su resonancia en la filosofía griega y en las ciencias de la Antigüedad y de la Edad Media y ha continuado reapareciendo en distintos momentos de la historia siempre que el hombre ha necesitado buscar soluciones científicas nuevas a sus problemas terrenos. No es el caso señalar ahora las varias manifestaciones y etapas de esta corriente humanista científico-naturalista que ha sobrevivido las circunstancias más hostiles en periodos de fanatismo religioso o sectario. Bastaría citar, como dignísimo precursor del periodo histórico que nos ocupa, el movimiento humanista, a la vez científico y literario, que produjo el «Renacimiento del siglo XII», representado por los grandes pensadores de la escuela de Chartres. Dichos pensadores, con todas las limitaciones de una ciencia experimental en su infancia, supieron acoplar los valores de la ciencia de la naturaleza y de la demostración racional con los literarios, los éticos y los espirituales. Desde nuestra perspectiva, estos fueron los verdaderos padres del humanismo europeo ${ }^{38}$.

\section{El HumANISMO ALFONSÍ Y ARISTÓTELES: «NATURALEZA》 Y «RAZÓN»}

Alfonso $\mathrm{X}$ fue sin duda heredero y beneficiario del «Renacimiento del siglo XII»; pero sobre todo fue heredero y a la vez impulsor del gran descubrimiento filosófico del siglo XIII: Aristóteles y sus libri naturales a través de las traducciones del árabe llevadas a cabo en

Road through Roncesvalles: Alfonsine Formation of Brunetto Latini and Dante-Diplomacy and Literature--», en R. I. Burns (ed.), Emperor of Culture, Alfonso X the Learned of Castile and His Thirteenth-Century Renaissance, Phildelphia, 1990, pp. 109-123. Cfr. H. S. Martínez, Alfonso X el Sabio, pp. 171-172; Id., «Alfonso X, Brunetto Latini y la historia de las primeras traducciones de la de la Ética aristotélica», Estudios Humanísticos. Filología, 39 (2017), pp. 245-277.

${ }^{37}$ H. J. Niederehe, Alfonso el Sabio y la lingüística de su tiempo, trad. de C. Melches, Madrid, Sociedad General Española de Librería, 1987, p. 83.

${ }^{38}$ Entre otros: Adelardo de Bath (h. 1080-h. 1152), Alain de Lille (h. 1114/1129-1203), Alejandro Neckham (1157-1217), Alfredo Sereshel (h. 1200-1227), Arnulfo de Orleans (s. XII), Conrado de Hirschau (1070-1150), Daniel de Morley (h. 1140-h. 1210), Diego García de Campos († d. 1218), Domingo Gundisalvo (h. 1150), Egidio Romano (1243/1247-1316), Juan de Garlandia (h. 1190-1270), Gautier de Châtillon (1135-1201), Godofredo de Eversley (s. XIII), Godofredo de Viterbo (h. 1169-1186), Guibert de Nogent († 1124), Guillermo de Conches (1090-1154), Guillermo de Saint Thierry († 1148), Henri d'Andali (h. 1250), Hermann el Alemán (h. 1220-1272), Honorio de Autun (1080-1151), Hugo de Santalla (s. XII), Hugo de San Víctor (h. 1097-1141), Juan de Salisbury (1120-1180), Juan Gil de Zamora (h. 1241-h. 1318), Pedro Alfonso ( $\dagger$ h. 1130), Pedro Compostelano (s. XII), Pedro Hispano (1215-1277), Pedro Palentino (s. XIII), Petrus Helias (1100-1166), Prisciano (h. 500), Ricardo de San Víctor (11101173), Roger Bacon (1214-1294), Thierry de Chartres († a. 1155), Uguccione da Pisa ( $† 1210)$, Ulric de Strasburg (h. 1225-1277), Alejandro de Villedieu (1175-124/1250), etc. Cfr. H. S. Martínez, El humanismo medieval y Alfonso X el Sabio, op. cit., cap. I, pp. 55-67. 
Toledo $^{39}$. Alfonso estuvo verdaderamente obsesionado con la filosofía racional aristotélica hasta el punto de que abrió su obra humanística por excelencia, la General Estoria, con la misma frase con la que Aristóteles inició la Metafisica: «Natural cosa es de cobdiciar los omnes saber los fechos que acahescen en todos los tiempos, tan bien en el tiempo que es passado, como aquel en que están, como en el otro que ha de venir» ${ }^{40}$.

Esta obsesión le venía de la firme convicción de que Aristóteles era el «mayor filósofo nacido de mujer» (como lo definió Averroes); el sabio por antonomasia que, con tan solo el auxilio de la razón natural: «fizo departimiento natural mente en todas las cosas deste mundo $\rangle^{41}$.

Esta convicción filosófica se manifiesta en Alfonso X ya en su obra programática, el Setenario, pero se expone claramente en su obra humanística por excelencia, las Partidas, donde, al hablar de las fuentes de la obra, dice: «E tomamos de las palabras e de los buenos dichos que dexaron los sabios, que entendieron las cosas razonadamente, segund natura» (Intr.). Entender las cosas «razonadamente», racionalmente, es penetrar en ellas «según su naturaleza», sin el apoyo previo de una autoridad externa que determine de antemano el resultado de la pesquisa. Para entender la posición de Alfonso en el campo del realismo-naturalismo de índole aristotélico-averroísta es necesario que nos fijemos en las expresiones «segund natura»y «natural mente», que machaconamente repite a cada paso, pues en ellas se encierra un componente esencial de su humanismo racionalista, secular y laico, que empieza a despertar en el siglo XIII a contacto con los libri naturales de Aristóteles y seguirá ininterrumpidamente hasta el Renacimiento.

En este contexto cultural, la obra alfonsí se halla íntimamente relacionada con el saber racional y experimental o, como le gustaba decir, «por razones objetivas»; de tal manera que lo coloca del lado de los filósofos, sobre todo de los de tendencia averroísta, que defendían la autonomía de la razón humana para dilucidar la verdad, en particular la verdad moral o sumo bien, antes bien que de los teólogos que, según el Rey Sabio, no proceden «segund la rrazón». La nota distintiva de esta toma de posición tan innovadora en pleno siglo XIII (el gran

\footnotetext{
${ }^{39}$ Alfonso sabía que la recepción del Aristoteles Latinus en Europa se había hecho a través de España y en gran medida desde su corte, de tal manera que no eran ninguna incongruencia los rumores que circulaban de un «Aristoteles hispanus»; de hecho, fue tal la familiaridad con el Estagirita que algunos escritores medievales y concretamente un cortesano suyo, Fr. Gil de Zamora, llegaron a afirmar que Aristóteles era nativo de España. Nada, pues, de extraño que en el scriptorium sevillano se conservasen un gran número de sus obras, tanto en árabe, como en latín y castellano. Cfr. F. Rico, «Aristoteles Hispanus. En torno a Gil de Zamora, Petrarca y Juan de Mena», Italia Medievale e Umanistica, X (1967), pp. 143-164.

${ }^{40}$ Aristóteles, Metafísica, 980a, 21, y Alfonso X, General Estoria, ed. completa de las cuatro partes, por P. Sánchez-Prieto Borja, et alii, 10 vols., Madrid, Biblioteca Castro, 20012009, Prólogo.

${ }^{41}$ Setenario, ed. cit., p. 27.
} 
siglo de la teología escolástica) es evidentemente la defensa de la autonomía de la razón humana en la búsqueda de la verdad, especialmente la verdad moral, en su doble dimensión: individual y social.

Entre las fuentes de las cuales hace uso para exponer sus ideas, especialmente las de origen aristotélico, hallamos la Ética nicomáquea, a partir de la cual Alfonso perfila su ideal de hombre perfecto, personificado en el sabio, cuyas características son la perfección espiritual y material. En lo espiritual, se rige por las leyes de la fe; en lo material, por las de la razón ${ }^{42}$.

«Naturaleza»y «razón», son los dos componentes que, según los «científicos» del siglo XIX, faltaron en el humanismo medieval. Nada más lejos de la verdad, por lo menos por lo que se refiere a Alfonso $\mathrm{X}$; pero no fue el primero en este campo. Quisiera señalar, como preludio a lo que diremos enseguida, que fueron precisamente los estudiosos madievales los que, en el proceso de recuperar los libri naturales de Aristóteles, y aun antes, pusieron en evidencia el valor de ambos componentes. Al tema se han dedicado volúmenes; pero por haber mencionado la Escuela de Chartres, quisiera señalar el trabajo que había sido llevado a cabo en sus especulaciones filosóficas, sirviéndome, a manera de ejemplo, de la incomparable oda de Alain de Lille, De planctu Naturae ${ }^{43}$. Según Alain de Lille, el hombre percibe el mundo que le rodea, el universo creado, como inteligible, como accesible a su razón natural; no solo, sino que lo percibe también como «camino» para llegar a la unión con Dios (et pacis glutino maritas caelica terris -y unes con el vínculo de la paz las cosas celestiales con las terrenales-), meta de todo humanismo religioso.

La especulación en torno al concepto de «naturaleza» como divinidad semi-independiente del Creador que, por influjo del neoplatonismo, dominó entre «chartrianos» y «victorinos» fue tema favorito de los humanistas del siglo XII, como Alain de Lille ${ }^{44}$. Alfonso,

\footnotetext{
${ }^{42}$ Cfr. H. Salvador Martínez, El humanismo medieval y Alfonso X el Sabio, pp. 30-31.

${ }^{43}$ Forman parte de este bellísimo poema alegórico las siguientes estrofas dedicadas a la «Diosa Naturaleza»:

O Dei proles, genetrixque rerum, vinculum mundi, stabilisque nexus, gemma terrenis, speculum caducis, lucifer orbis, Pax, amor, virtus, regimen, potestas, ordo, lex, finis, via, lux, origo, vita, laus, splendor, species, figura, regula mundi,

Quae, tuis mundum moderans habenis, cuncta concordi stabilita nodo nectis, et pacis glutino maritas caelica terris. (vv. 1-12)

T. Wright (ed.), Anglo-Latin Satirical Poets, Rolls Series, vol. II, 1872, p. 458.

${ }^{44}$ Cfr. Ernst Robert Curtius, European Literature, cap. VI: «The Goddess Natura», el apartado $4^{\circ}$ está dedicado a Alain de Lille. Cfr. H. S. Martínez, El humanismo medieval..., op. cit., pp. 262-265, notas 18 y 19 .
} 
amante de la mitología y de los clásicos, evidentemente conocía la alegoría poética de la «Diosa Naturaleza» ${ }^{45}$. En este caso, sin embargo, descarta la idea neoplatónica de los pensadores de Chartres, refugiándose del vendaval del neoplatonismo pagano, recurriendo a la terminología aristotélico-escolástica de nueva acuñación que clasificaba el concepto de naturaleza en dos modalidades: natura naturans [《natura naturador», o naturaleza engendradora], a la cual identificaban con Dios; y natura naturata [«natura naturada», o naturaleza creada], que era identificada con el cosmos, tal vez sin caer en la cuenta de que también esta clasificación tenía una buena dosis de platonismo panteísta. Escribe en el Setenario:

Natura es la segunda parte deste Setenario, que muestra las cosas ónde nasçen e cómmo e en qué guisa obran por ssipse e unas con otras, e otrosí en qué manera se desffazen. Et esto partieron los sabios en siete partes: ... Et la primera es natura naturador [natura naturans]; esta es Dios, que ffué siempre e sserá e de qui salen todas las otras e en él sson ençerradas. Et esta avían por el su ssaber e por el su poder e por el ssu querer. La ssegunda es llamada natura naturada [natura naturata], que quiere dezir que fue fecha del naturador. Et esta son las criaturas a que llaman ángeles, que ha en sí poder e vertud de obrar sobre las cosas que quiere Dios que ffaga cada uno ssegunt el offiçio que ha... (pp. 26-27).

Para Alfonso, como para los pensadores de Chartres, «Natura» (naturata) es una especie de demiurgo platónico, o inteligencia creadora, «que ha en sí poder e vertud de obrar sobre las cosas que quiere Dios que ffaga cada uno ssegunt el offiçio que ha...». Esta inteligencia creadora, según la escuela alejandrina, era el alma del mundo, distinta de la causa primera (o Dios creador) ${ }^{46}$.

Prescindiendo de los errores en que, por desconocer los textos aristotélicos que se harán populares poco después, pudieran caer algunos de los pensadores de Chartres y de París, arrastrados por su fervor científico, no cabe duda que ambas escuelas tuvieron un gran impacto en el desarrollo del humanismo alfonsí en su vertiente

${ }^{45}$ Del conocimiento del De planctu naturae por Alfonso X no debe cabernos la menor duda. El Archivo del Cabildo de la catedral de Toledo conserva un manuscrito misceláneo (MS 47-15) que, según el parecer de los expertos, fue copiado en el scriptorium alfonsí; en él ha sobrevivido, junto con obras de Cicerón, Boecio, Aristóteles y varios filósofos árabes, una espléndida copia de la obra de Alain de Lille. En el fol. 1 podemos admirar una ilustración de la Diosa Naturaleza como doncella de belleza incomparable, cuyos rasgos estilísticos coinciden con las ilustraciones de las Cantigas y otras obras del Scriptorium alfonsí. Cfr. J. M. Millás Vallicrosa, Las traducciones orientales en los manuscritos de la Biblioteca de la catedral de Toledo, Madrid, 1942, pp. 55-64; y G. D. Greenia, «A New Manuscript Illuminated in the Alphonsine scriptorium», The Bulletin of the Cantigueiros de Santa Maria, 2 (1988-1989), pp. 31-42; y H. S. Martínez, op. cit., pp. 50-52, nota 11.

${ }^{46}$ Sobre el platonismo panteísta entre los varios intelectuales de Chartres, cfr. H. S. Martínez, El humanismo medieval y Alfonso X el Sabio, op. cit., cap. I, pp. 55-67. 
científico-filosófica; de tal manera que, en líneas generales, se puede decir que Alfonso sigue el esquema del humanismo cristiano lanzado por Chartres que ve, tanto en las artes como en las ciencias, el «remedio», o los «instrumentos», para elevar la naturaleza debilitada por el pecado original hasta hacerla llegar al conocimiento racional de Dios y de sus atributos. Este es el sustrato profundamente cristiano que, no obstante las grandes innovaciones provenientes de las ciencias y la filosofía aristotélica, sobrevive en la obra del Rey Sabio y paradójicamente lo que le hace ser un humanista secular, tal vez un tanto agnóstico, pero sin ser ateo.

Reconstruir el concepto de humanismo medieval al hilo de la oda de Alain de Lille, con su énfasis en «naturaleza» como «origen», «orden», «regla del mundo», es, más allá de su impresionante belleza literaria como poema, alejar el concepto de «humanismo medieval» del que será más tarde el «humanismo literario» de los florentinos, con su amor por los clásicos y su esfuerzo por imitarles en el estilo, pero sin referencia alguna al sobrenatural, y aproximarlo al «humanismo científico» del que hablamos más arriba, pero sin olvidar que también este carece de la dimensión del sobrenatural en la vida del hombre, posición superada por el humanismo alfonsí que ve el mundo que nos rodea como instrumento científico en el proceso de la adquisición del conocimiento necesario para vivir en un orden social y como «camino» para llegar a Dios. Todo el proceso metafísicoteológico del siglo XIII, el gran siglo de la Escolástica, está basado en este ascenso racional de las creaturas, como huellas, que llevan al Creador.

Alfonso X se halla en plena consonancia con el humanismo científico chartriano, cuando sostiene que el mundo nos revela y nos sirve para conocer a Dios:

Cobdiciando que las grandes vertudes et maravillosas que Dios puso en las cosas que Él hizo, que fuessen conoscidas e sabudas de los omnes entendudos, de manera que se podiessen aiudar dellas, porque Dios fuesse dellos loado, amado et temido ${ }^{47}$.

Dadas, pues, las objeciones que han sido puestas al humanismo medieval desde distintas perspectivas, quisiera señalar algunos textos en los que se pone en evidencia el influjo de la ciencia y la fílosofía aristotélica en relación con los temas más frecuentemente cuestionados: Naturaleza y Razón.

Antes de pasar a exponer lo que entiende por «naturaleza», me parece necesario señalar, ya desde ahora, qué es lo que Alfonso entiende por «razón» cuando hablamos de ella en nuestro ensayo porque es un concepto que domina todos los aspectos de su concepción

${ }^{47}$ Libros de las estrellas de la ochava esfera, M. Rico y Sinobas (ed.), I, p. 13. (infra n. 51). 
humanística de la actividad del hombre como ser racional en el cosmos:

Rrazón es atal commo la lunbre entre las tinieblas, ca ella alumbra el entendimiento e ffaz connosçer la natura e ssabe cierta mente las cosas e demuéstralas rrazonando e departiendo [exponiendo] lo que sse muestra por ssignifficança [metáfora, alegoría], e ordena los ffechos cada uno ó [donde] deve, e dales acabamiento commo convyene ${ }^{48}$.

El estudio racional de las ciencias de la naturaleza tiene unas implicaciones extraordinarias cuando se trata de entender el alcance del humanismo alfonsí, ya que va más allá de la física mecánica y orgánica (estudio del macrocosmos) para penetrar en el ámbito de las ciencias sociales. Este estudio fue el resultado de la difusión de los libri naturales de Aristóteles, y representa una de las características más singulares del humanismo de finales del siglo XII y a lo largo del XIII. «Más hallarás en los bosques que en los libros», había sido ya el lema inculcado por San Benito a sus monjes en el siglo vii. Pero el siglo XIII, siguiendo los pasos de los estudiosos de Chartres, fue muy diligente en llevar dicho lema a la práctica, volviendo repetidamente su mirada hacia la naturaleza para reflexionar sobre ella y su composición.

La preocupación por la naturaleza tiene ahora esta doble vertiente, porque es la madre de todo (parens omnia) y porque es principio explicativo de todo (ratio omnium); y sobre todo, como se dijo, porque es el camino para llegar a Dios (iter in Deum). El estudio y escrutinio de la naturaleza durante el renacimiento del siglo XII tuvo siempre esta doble faceta sacro-profana y fue una verdadera obsesión entre científicos y teólogos. Bastaría citar el caso de Alberto Magno (1193-1280), reconocido como fundador de la ciencia experimental y al mismo tiempo sabio teólogo, maestro y guía espiritual de Santo Tomás (h. 1225-1274), padre de la Summa Theologica, la expresión por excelencia de la teología del siglo XIII.

Si a Alfonso X le fascinaron los libri naturales de Aristóteles fue porque en ellos pensó hallar la vía al «otro» conocimiento del mundo, el científico y racional. En ellos halló, por primera vez en la historia del humanismo, todo lo que a la vida del hombre, los animales, las plantas y los minerales se refiere; y sobre todo halló un nuevo método para buscar la verdad objetiva y experimentalmente y no ya solo por mediación de la auctoritas de la revelación, la Biblia y los Padres de la Iglesia. Alfonso frecuentemente se apela en su argumentación para probar racionalmente una determinada proposición a la «natura» de las cosas, distinguiendo entre natura y naturaleza:

\footnotetext{
${ }^{48}$ Setenario, p. 46. Cfr. H. S. Martínez, op. cit., pp. 198-200.
} 
Naturaleza tanto quiere dezir como debdo que han los homes unos con otros por alguna derecha razón en se amar et se querer bien. Et el departimiento [distinción] que ha entre natura et naturaleza es este: que natura es una virtud que face ser todas las cosas en aquel estado que Dios las ordenó, et naturaleza es cosa que semeja a la natura, et que ayuda a seer et a mantener todo lo que descende della (Partida II, XXIV, 1).

Ésta era la gran novedad en el progreso científico racional de su época: «Lo que faltaba al siglo XII para reconocer una realidad concreta bajo un mundo de símbolos era la concepción de una naturaleza dotada de una estructura en sí, aunque fuera débilmente. Estamos en vísperas del día en que esta concepción va a formarse y es a la física aristotélica a la que lo deberá el siglo XIII ${ }^{49}$.

La posición intelectual de Alfonso encaja perfectamente con esta línea de pensamiento. De ahí que su humanismo, como en general el de sus contemporáneos, sea un humanismo total; en el sentido de que abarca tanto las letras, divinas y humanas, como las ciencias; así como un nuevo método en que apoyar su argumentación, fundado en la naturaleza misma de las cosas («segunt natura»). Esta es una de las diferencias fundamentales con respecto al humanismo clasicista del siglo XV que, como hemos venido diciendo, se centra exclusivamente en una parcela muy limitada del saber, como es el conocimiento e imitación de la latinidad clásica, mediante el estudio de la retórica y la elocuencia.

No hallo mejor forma de explicar este contraste de intereses entre ambos humanismos que citando el procedimiento usado por Leonardo Bruni para clasificar la producción aristotélica en su Vita Aristotelis (1429-430). Bruni clasifica las materias de los libros del Estagirita en cuatro categorías: en primer lugar, pone los libros sobre la elocuencia y la persuasión; luego, los de educación civil y moral; seguidos de los de lógica, esto es, el llamado Organon; y finalmente, los que tratan sobre los secretos de la naturaleza, los libros de física o filosofía natural, en cuya categoría, por cierto, no cita ninguno. Esta clasificación y el orden de prioridades nos lo dice todo sobre la diferencia fundamental entre el humanismo medieval-alfonsí y el latino-clasicista: a este no le interesaban los libros de filosofía y de ciencias, sino que, como dice Rico, su «mínimo común denominador era cambiar la enseñanza, cimentándola en la eloquentia, en las letras antiguas, era etapa primera e imprescindible de toda andadura valiosa $»^{50}$.

Fue sin duda su interés por las innumerables facetas del naturalismo aristotélico lo que llevó a Alfonso X a explorar todas las obras conocidas de los antiguos griegos y latinos, así como de los sabios

${ }^{49}$ E. Gilson, La philosophie au Moyen Age, $2^{\mathrm{a}}$ ed., Paris, Payot, 1952, p. 343.

${ }^{50}$ F. Rico, Nebrija, op. cit., p. 73. 
musulmanes y judíos de su tiempo, ya fuesen literarias, históricas o científicas, para componer las suyas. El humanismo alfonsí se extendió también a las ciencias en cuanto actividad humana; en este campo, sin embargo, Alfonso, en realidad, se ocupó principalmente de una de ellas que era la ciencia de punta de su época, la astronomía y sus aplicaciones en la astrología, componiendo dieciséis libros que forman Los libros del saber de astronomía ${ }^{51}$. Ni las matemáticas, ni la física, como ciencia de la naturaleza, ni la medicina, a pesar de sufrir gravísimas enfermedades y estar rodeado de médicos, le interesaron hasta el punto de dedicarles sendos tratados, aunque sí hizo infinidad de referencias a todas ellas en sus obras; será en los Lapidarios donde, al hablar de la utilidad de las piedras para la salud humana, se ocupará más directamente de la medicina ${ }^{52}$. Visto desde la perspectiva de la revolución cultural de la obra alfonsí en todos los campos del saber, el humanismo promovido por el Rey Sabio no fue solo una vuelta a los clásicos greco-latinos sino que abarcó también muchos otros matices, como son el filosófico, el científico y sobre todo el social y, dentro de este, como hemos venido diciendo, el lingüístico.

\section{NaturaleZa y LENGUA}

Para ilustrar de alguna manera esta visión humanista totalizadora, y sin salirnos del parámetro de «naturaleza», examinaré una de las múltiples acepciones que Alfonso incluye bajo este concepto que es tal vez la menos estudiada.

Para el Rey Sabio el concepto de naturaleza abarca no solo el mundo exterior que nos rodea, o macrocosmos, sino también todos los aspectos del hombre, tanto como entidad física en el cosmos que como entidad espiritual y moral en la sociedad, pues ésa es su «natura». Esta convicción le viene a Alfonso no tanto de la teología de la época, cuanto de su contacto con las últimas novedades del pensamiento pagano y concretamente con los textos aristotélicos que clasificaban la composición de las realidades mundanas, «segunt natura», en espirituales y temporales: «Et por ende Aristótiles e los otros philósophos ffablaron en esta rrazón muy conplidamiente e mostraron

${ }^{51}$ Libros del saber de astronomía del rey d. Alfonso X de Castilla, M. Rico y Sinobas (ed.), 5 vols., Madrid, Tipografía de Eusebio Aguado, 1863-1867; y A. Cárdenas, A Study and Edition of the Royal Scriptorium Manuscript of El Libro del saber de astrología by Alfonso X el Sabio, 4 vols., Doctoral Dissertation, Madison, University of Wisconsin, 1974.

${ }^{52} \mathrm{Cfr}$. E. Procter, «The Scientific Works of the court of Alfonso X of Castile: the King and his collaborators», Modern Languages Review, 40 (1945), pp. 12-29, p. 28; J. H. Nunemaker, «Obstetrical and Genito-Urinary Remedies of Thirteenth-Century Spain», Bulletin of the History of Medicine, 15 (1944), pp. 162-179, donde el autor estudia la medicina en los Lapidarios; y L. Fernández Fernández, Arte y ciencia en el scriptorium de Alfonso X el Sabio, El Puerto de Santa María, Univ. de Sevilla y Cátedra de Alfonso X el Sabio, 2013, pp. 135-211. 
por ella todas las cosas, cómmo eran compuestas e ordenadas segunt natura spiritual e tenporal $»^{53}$.

La Primera Partida está dedicada a los temas que pertenecen a la «natura spiritual» del hombre la cual «face al ome conoscer a Dios por creencia»; sin embargo, añade inmediatamente: «Estas leyes son establecimientos, porque los omes sepan bivir bien e ordenadamente segund el plazer de Dios: e otrosí segund conviene a la buena vida deste mundo [...] Otrosí como bivan los omes unos con otros en derecho e en justicia (I, I, 1). La expresión «bivir bien e ordenadamente segund el plazer de Dios», en opinión de J. Ferreiro Alemparte, concuerda con la felicidad humana según la Ética a Nicómaco ${ }^{54}$. La intención de Alfonso en su gran obra jurídica es ordenar la vida de sus súbditos «segund el plazer de Dios» (Primera Partida), pero también según unos principios ético-racionales (Partidas II-VII). En este contexto, «la buena vida» y «la buena conducta» están a significar el comportamiento que todo ser racional debe manifestar en sus relaciones sociales y económicas como ser político, cuya finalidad es crearse una felicidad terrena, una buena vida, mientras trascurre su residencia en la tierra ${ }^{55}$.

Dentro de estas dos categorías, de la espiritualidad y la racionalidad del hombre, según una escala de innumerables variaciones, cabe todo lo creado. Una de estas variaciones del concepto de «naturaleza» en su dimensión social, es la acepción de «naturaleza» como «patria». Hablando en las Partidas del concepto de «patria» y del amor que todos los hombres deben tener por ella, escribe:

Esto fizo [Dios] porque entendió que esta es la primera naturaleza et la mayor que los homes pueden haber con la tierra en que han de vevir, ca maguer es muy grande la otra que ganan con ella por crianza que les así como ama que los gobierna, et otrosí la que toman morando en la tierra aprendiendo et usando en ella las cosas que han de facer, et se les face así como ayo et maestro que les enseña lo que han de aprender, con todo eso por mayor tovieron los sabios antiguos que fablaron en todas las cosas muy con razón, aquella naturaleza que de suso diximos que los homes han con la tierra por nascer en ella, ca esta les es así como madre de que sallen al mundo et vienen a seer homes (II, 20, 1, las cursivas son nuestras).

\footnotetext{
${ }^{53}$ Setenario, p. 27.

${ }^{54}$ «Recepción de las Éticas y de la Politica de Aristóteles en las Siete Partidas del Rey Sabio», Glossae: Revista de Historia del Derecho Europeo, 1 (1988), pp. 97-133.

${ }^{55}$ Concuerdan con este razonamiento aquellos que dicen que ser feliz es vivir bien u obrar bien, pues ordinariamente se considera sinónimo de felicidad una Buena vida y una Buena conducta (Ética a Nicómaco, en J. Ferreiro Alemparte, «Recepción», p. 116).

Para un análisis de las implicaciones filosóficas y políticas del énfasis alfonsí en la consecución de la felicidad en el mundo presente frente a la salvación en el más allá, cfr. F. PradoVilar, «The Gothic Anamorphic Gaze», pp. 67-100; Id., «De la Astromagia a la Nigromancia», Catálogo de la Exposición de Murcia, 2009, p. 449.
} 
Las consecuencias que extrae Alfonso de este concepto de naturaleza como «patria» son extraordinarias: la tierra nativa («que dicen en latín patria», Partida, I, 1, 2), es la madre generadora en lo físico-biológico sin la cual, la «segunda madre» (la sociedad como educadora), no sería posible; esta es la que constituye el fundamento de todos los derechos y prerrogativas que distinguen al hombre de los animales. De este concepto de naturaleza como entidad moral-social deriva el derecho natural (ius naturale) y su correlativo, el derecho de gentes (ius gentium) que «en latín tanto quiere decir como derecho comunal de todas las gentes el qual conuiene a los homes e non a las otras animalias» (Partida I, 1, 2) ${ }^{56}$.

Alfonso ve también bajo este mismo concepto social de naturaleza, engendradora y educadora, el origen de la lengua natural hablada, prerrogativa única del ser humano que lo separa de los brutos animales y que constituye la manifestación más evidente de su racionalidad, permitiéndole comunicar con sus semejantes como ciudadano de la misma patria. El hombre es, por naturaleza, un animal sociable. Esta es una visión naturalista del hombre que Alfonso aprende de Aristóteles, según la cual, la naturaleza es la madre de todo (parens omnia) ${ }^{57}$.

Sin pretender entrar en aspectos antropológicos del humanismo alfonsí, campo totalmente ignorado por los investigadores de su obra, quisiera simplemente señalar que, la selección de la lengua hablada por las tres etnias que componían su reino, tuvo su raíz, muy lógica, en el contexto del humanismo científico-naturalista de índole aristotélica que profesó el Rey Sabio. El hombre, para Alfonso -nos lo recuerda en infinidad de pasajes-, no es solo un manojo de huesos, nervios, músculos y venas por las que corre la sangre, sino que es por encima de cualquier otra prerrogativa natural, un animal racional hablante: razón y lenguaje son prerrogativas exclusivas del hombre que lo separan de la bestia, como había intuido ya Aulo Gelio. Desde esta perspectiva filosófico-antropológica, la decisión de optar por el castellano en lugar del latín es perfectamente cónsona con su concepto de naturaleza y de habla natural, o lengua materna, pues es la manifestación espontánea de la sociabilidad esencial del hombre, en oposición a la artificiosidad de una lengua aprendida, como hubiese sido el latín.

${ }^{56}$ «Ni el Derecho Romano ni el mismo Aristóteles, escribe J. A. Maravall, han podido dar a Alfonso X esa otra concepción política del territorio - de un territorio a la vez extenso y esencialmente ligado a la vida y a la historia de la comunidad-, que es lo más característico de su pensamiento. Es quizá, esa fusión de pueblo y territorio uno de los aspectos más propios de las formas políticas europeas bajomedievales; y dudo que, antes de 1260, haya habido nadie que le diera más completa y clara elaboración doctrinal que Alfonso X» (Estudios de historia del pensamiento español, I, $2^{\mathrm{a}}$ ed., Madrid, Ediciones Cultura Hispánica, 1973, p. 107).

${ }^{57}$ Del naturalismo alfonsí y del uso de la lengua vulgar como expresión de ese naturalismo, se ha ocupado Filgueira Valverde, poniendo de relieve que la finalidad de Alfonso al lanzar esta idea era equiparar en civilización lo hispánico a lo romano y a lo semítico, impulsando así la lengua vulgar (Las Cantigas, Madrid, Odres Nuevos, pp. xxii-xxiii, y xxv). 
Ésta es la característica más singular que identifica el humanismo científico-naturalista de Alfonso X: «ejercer en romance todo ministerio de saber», y así elevar la lengua natural, vernácula, el castellano, a la categoría de lengua de cultura. Fruto también de este mismo concepto de promoción de la lengua y la cultura vernácula, como manifestación espontánea de la naturaleza racional del hombre, fue el uso del gallego-portugués, lengua en la que compuso toda su obra poética, religiosa y profana.

Si la preocupación por todas las ramas del saber y la promoción de las aspiraciones del ser humano marcan el carácter de un escritor y su obra, lo que individualiza inconfundiblemente el humanismo de Alfonso X es el hecho de que su obra fuese escrita en lengua vernácula para que pudiesen beneficiarse de ella todos los que no entendían el latín y «que todo omne que aya buen entendimiento, aunque no sea letrado, la entendiera ${ }^{58}$.

Si hemos querido poner un énfasis particular en el aspecto naturalista del humanismo alfonsí y en su dimensión social es porque fue un movimiento cultural innovador, me atrevería a decir, revolucionario, que coincide con la etapa decisiva del proceso de establecimiento de la lengua vernácula, el castellano. De tal manera que ambas manifestaciones, humanismo naturalista y humanismo vernáculo, forman parte del mismo fenómeno y son inseparables.

El tema de la lengua natural, espontánea, en oposición a la aprendida, artificial, volverá a debatirse cuando el humanismo italianoclasicista haya cobrado plena carta de ciudadanía europea. Entre los opositores a la artificialidad de la lengua debemos mencionar a un lingüista de excepción, Juan de Valdés (1505-1541), el cual, a pesar de reconocer que Nebrija era un gran latinista, se distancia vigorosamente de su método de enseñanza del castellano por varias razones, entre ellas, y la más fundamental, porque está convencido, como anteriormente lo había estado Alfonso X, de la plena autonomía del castellano del latín. Mientras para Nebrija la reducción a arte, a reglas, era el mayor honor que podía hacérsele a la lengua vulgar, equiparándola al latín, Valdés, que según su editora, «En esto le sobrepasa con una visión mucho más moderna», nos dice:

... porque he aprendido la lengua latina por arte y libros, y la castellana por uso, de manera que de la latina podría dar cuenta por el arte y por los libros en que la aprendí, y de la castellana no, sino por el uso común de hablar... ya sabéis que las lenguas vulgares de ninguna manera se pueden reducir a reglas de tal suerte que por ellas se puedan aprender; y siendo la castellana mezcla de tantas otras, podéis pensar si puede ninguno ser bastante a reducirla a reglas ${ }^{59}$.

\footnotetext{
${ }^{58}$ D. Juan Manuel, Crónica abreviada, R. L. Grismer (ed.), pp. 37, 7-9, $20-21$.

${ }^{59}$ Juan de Valdés, Diálogo de la lengua, C. Barbolani (ed.), Madrid, Cátedra, 1990, pp. 121 y 153 .
} 
Juan de Valdés fue el que en pleno Renacimiento italiano y viviendo en Italia dio al castellano la categoría de la auctoritas, pero no basada en la auctoritas de las obras escritas en castellano, sino en el uso de la lengua común, testimoniada por los refranes. Los refranes a los que se refiere Valdés no son los de los cultos humanistas, como los adagia de Erasmo o los emblemata de Alciato, sino «los tomados de dichos vulgares, los más dellos nacidos y criados entre viejas, tras del fuego hilando ruecas; y los griegos y latinos, como sabéis, son nacidos entre personas doctas y están celebrados en libros de mucha doctrina. Pero, para considerar la propiedad de la lengua castellana, lo mejor que los refranes tienen es ser nacidos en el vulgo» (op. cit., p. 127).

Independientemente del valor científico que se quiera dar a la posición de Valdés, el mensaje que encierra se relaciona íntimamente con la opinión de Alfonso X, como este, sostiene que el origen de una lengua está basado en la cultura popular desarrollada conjuntamente en esa lengua, y dicha base no tiene otro principio y fundamento más que la naturaleza humana racional. De ahí también el nombre que hemos dado a su humanismo: vernáculo, es decir, autóctono, natural y espontáneo. Solo los hombres pueden razonar y solo los hombres pueden expresar sus pensamientos espontáneamente mediante la palabra. Alfonso, aristotélico de convicción, no podía aceptar el latín como lengua oficial de su programa cultural porque no era lengua «natural», espontánea, sino artificial, mientras que el castellano era la expresión natural y espontánea, que se mamaba con la leche materna y, como tal, la aceptaban todos los súbditos de su reino ${ }^{60}$.

El humanismo alfonsí representa un concepto integral del hombre y del mundo que le rodea, e incluye tanto el humanismo «filantrópico», como el «paideico» del cual hablamos más arriba. El objeto de este humanismo es el estudio del ser humano en su totalidad, como entidad compuesta de materia y forma, o cuerpo y espíritu; binomio que, según la filosofía aristotélica, lo identifica y lo diferencia como ser único en el universo, y establece sus relaciones únicas con el creado. Es un humanismo que, además de preocuparse del hombre desde la perspectiva de su condición físico-material, como ser en la creación, en cuanto representa la síntesis de las demás criaturas (microcosmos), se ocupa también del hombre como entidad espiritual (persona). Esta síntesis fue expuesta en un significativo pasaje de la General Estoria que conviene recordar antes de cerrar este estudio:

Tres poderes ha ell alma, assí como nós lo aprendimos por palabras de Aristótil, e de Plinio, e de Augustín, e de Orígenes, e de Dionís e dotros muchos quelo cuentan por ellos, e aún ante desto quelo ordenó assí nuestro sennor Dios, por las naturas que dio a las cosas; e aquellos

\footnotetext{
${ }^{60} \mathrm{De}$ los dos traductores del Libro de los juicios de las estrellas, uno judío y el otro cristiano, se dice que tenían por «lengua materna» el castellano. Cfr. H. S. Martínez, El humanismo medieval y Alfonso $X$, op. cit., p. 403, nota 62.
} 
tres poderes dell alma son estos [...]: poder veietativo, poder sensitivo e poder discretiuo. El poder veietativo dell alma es fazer crescer los cuerpos, onde poder ueietatiuo tanto quiere dezir como acresçentativo o acresçentador [...] el poder sensitiuo dell alma tanto quiere dezir como sentidizo o sentidor [...] El poder discretiuo dell alma es en los omnes, e en los ángeles buenos e malos, e en Dios. E esta palabra discretiuo quiere dezir tanto como departidizo o departidor; e esto es, que ell omne e ell ángel e Dios han la natura deste poder dell alma, fascas natura de poder e saber departir [distinguir] entrel bien e el mal, e quál es la buena cosa e quál la mala, et dezir lo por palabra ${ }^{61}$.

Este texto, basado en el tratado De anima de Aristóteles, muy comentado en las aulas medievales, le ofrece a Alfonso la oportunidad de fundar en él las dos manifestaciones esenciales sobre las que descansa la vida de toda sociedad civilizada, el derecho natural y el derecho de gentes. El primero tiene su fundamento en el alma sensitiva, o sentidora (poder sensitivo), según el cual «... el másculo se ayunta con la fembra, a que llamamos casamiento, e por él crían los omes sus fijos e todas las animalias»; el segundo, o «poder discretiuo», se funda en el alma razonable y «conviene a los omes e non a las otras animalias» (I, I, 2). Este «poder discretiuo» es también el fundamento del derecho comunal, o derecho de gentes que, según Alfonso, «fue hallado con razón [es decir, mediante el ejercicio de la razón], e otrosí por fuerça [es decir, por necesidad], porque los omes non podrían bien bivir entresí en concordia e en paz si todos non usasen dél» (ib.).

En otras palabras, la vida social humana se funda en un pacto racional llevado a cabo entre seres racionales para salvaguardar la paz y el bienestar social ${ }^{62}$.

El derecho natural regula todas las leyes de la naturaleza, las cuales, a diferencia de las leyes humanas, son inmutables:

la natura non puede dexar, nin desviarse de obrar segund la orden cierta que usó Dios porque obrase, assí como fazer noche, e día, e frío, e calentura: e otrosí que los tiempos non recudan [vuelvan] a sus razones segund el movimiento cierto del cielo, e de las estrellas, en que Dios puso virtud e poder de ordenar la natura. Nin puede fazer otrosí, que lo pesado non descienda, e que lo liviano non suba. E por eso dixo Aristóteles que la natura non se faze a obrar en contrario, e esto quiere tanto dezir como que siempre guarda una manera, e orden cierta, porque obra. E otrosí non puede fazer algo de nada, mas todo lo que se faze por ella, conviene que se faga de alguna cosa, assí como de un elemento, e de otro, o todos los quatro elementos de que

${ }^{61} G E$, I, pp. 572b-573a (las cursivas son nuestras). Véase también, a propósito de la teoría de los cinco sentidos, el comentario que trae la Partida, II, XIII.

${ }^{62}$ Sobre el concepto y la función de la razón, tanto a nivel personal como social, en Alfonso vid. supra. 
se engendran todas las cosas naturales o compuestas (Partida I, tít. IV, ley XLVII).

En este mismo título Alfonso discute el milagro y dónde encaja dentro de las leyes inmutables de la naturaleza. Naturalmente, el Rey Sabio no tiene una explicación científica o racional, sino simplemente dice que «este poder es apartadamente [exclusivo] de Dios» y

Quando obra por él, a lo que faze dízenle miraglo, porque quando acaesçe, es cosa maravillosa a los omes e a las gentes; e esto es, porque las gentes veen cada día los fechos de la Natura, e por ende quando alguna cosa faze contra ella, maravíllanse de donde viene $(i b$.$) .$

Estos textos están cargados de aristótelismo-averroísta (los astros como responsables del orden natural, imposibiliad de la creación ex nihilo, etc.) y al mismo tiempo de terminología escolástica. En la jerarquía en que se hallan escalonados los seres creados, de los seres vegetativos, los sensitivos y los racionales a los ángeles y a Dios, según Alfonso, las cosas son afines entre sí y reductibles a unos mismos principios. Según esto, el hombre posee, amén de la existencia, «el poder dell alma que dixiemos ueietatiuo, que es en las plantas e en las otras animalias [...] et el sensitivo, como es en las otras animalias, e [...] el discretivo, comunal con los ángeles e con Dios» ${ }^{63}$. Por tanto, el hombre es una suerte de mundo pequeño, un microcosmos; y, a su vez, el cosmos es un $\mu \alpha \kappa \rho o ́ \varsigma \alpha ́ v \theta \rho \omega \pi o \varsigma$, un hombre inmenso, «con ell oio del sol» (GE, I, p. 210b), o donde «el Nilo ombligo es del mundo, quel mantiene en los humores y l'atempra en los feruores» $\left(G E .\right.$, I, p. 117b) ${ }^{64}$.

Es este, sin duda, un lenguaje metafórico, muy típico del pensamiento alfonsí, que nos ayuda a extraer de estos textos filosóficos su idea de humanismo, al trasmitirnos de manera muy eficaz su visión antropocéntrica de la historia en la que se presenta al hombre como el centro y la medida del universo pues, además de ser su síntesis, es la única criatura que posee el don de la racionalidad y la capacidad de distinguir entre el bien y el mal «et dezirlo por palabra», que es atributo primordial y único de la naturaleza humana ${ }^{65}$.

Las implicaciones de este planteamiento filosófico-humanístico son extraordinarias y sin precedentes en el proceso de la adquisición

\footnotetext{
${ }^{63} G E$ I, p. 573a.
}

${ }^{64} \mathrm{La}$ historia del mundo, por otra parte, pasa por las mismas edades y conoce las mismas incidencias que la vida del hombre. Cfr. F. Rico, Alfonso y la GE, Barcelona: Ariel, pp. 127-128.

${ }^{65} \mathrm{La}$ imagen del hombre como centro del universo en el ámbito del humanismo medieval tuvo, entre muchas otras manifestaciones, su expresión más acertada en una miniatura del $\mathrm{Li}$ ber Divinorum Operum de Hildegarda de Bingen (1098-1179), conservada en el Codex Latinus de la Biblioteca Estatal de Lucca (Italia). Cfr. Santa Hildegarda de Bingen, Liber Divinorum Operum. Libro de las Obras Divinas, traducción del latín y notas de R. Renedo, 2007, p. 41. [Ilustración 2]. 
del saber: si el hombre es un mundo en pequeño y el saber es unitario, esto significa que tanto si el hombre sale de sí, hacia el mundo que le rodea, como si entra dentro de sí, no hace más que recorrer un itinerario que en cualquier caso le lleva a la sabiduría, que es el conocimiento del mundo y últimamente de Dios; y esto es así porque «... lo ordenó assí nuestro sennor Dios, por las naturas que dio a las cosas ${ }^{66}$.

Esta última frase revela claramente la nueva realidad filosófica proveniente de los textos aristotélicos, privilegio que no tuvieron los pensadores de Chartres. Alfonso repite hasta la saciedad que el saber es un proceso de ida y

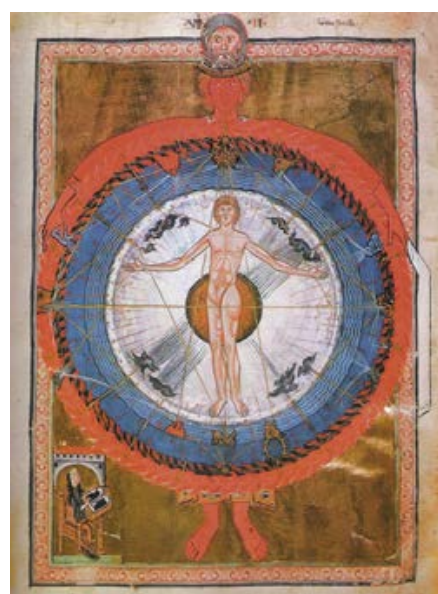

Fig. 2. El hombre centro del universo, según Hildegarda de Bingen, Liber Divinorum Operum (1163-1173). vuelta, es decir, viene de Dios, revela a Dios y acerca a Dios; y no solo en el sentido de descubrir a Dios en y por las criaturas como inculcaba ya San Pablo en su Carta a los romanos (I, 20), que Alfonso hace suya en el prólogo de los Libros de las estrellas de la ochava esfera ${ }^{67}$; sino también en el sentido de que el conocimiento parte del interior: «Porque esta es la cosa que tod omne debe saber primeramientre, fascas cómo mantenga a ssí mismo e se reconosca qué cosa es; después puede saber las otras cosas que fueren menester, et connoscer a Dios ${ }^{68}{ }^{6}$. Este itinerario en busca del saber, hacia fuera y sobre todo hacia dentro, no es en sí algo nuevo («conócete a ti mismo» [nosce te ipsum] era ya una vieja máxima socrática esculpida en el templo de Delfos), pero Alfonso le da una nueva dimensión ética y social al incluir en su formulación "cómo mantenga a ssí mismo».

No podía ser diversamente; en su misión de rey y educador de su pueblo, Alfonso no olvida nunca el ámbito social del saber y la función del sabio. De ahí su interés primordial por las ciencias del hombre, tanto en su dimensión físico-natural (Lapidario, Tablas astronómicas, Libros del saber de astrología), como de aquellas otras que se ocupan del hombre como entidad socio-moral, con unos derechos y unas obligaciones (Setenario, Espéculo, Fuero real, Partidas). Es un humanismo que incluye también todos aquellos aspectos que tratan de las necesidades que derivan de la espiritualidad y sociabilidad del ser humano, como son los juegos, el ocio y el recreo, temas a los que

\footnotetext{
${ }^{66} G E$, I, p. 572 b.

${ }^{67}$ «Cobdiciando que las grandes vertudes et maravillosas que Dios puso en las cosas que Él hizo, que fuessen conoscidas e sabudas de los omnes entendudos, de manera que se podiessen aiudar dellas, porque Dios fuesse dellos loado, amado et temido» (M. Rico y Sinobas (ed.), I, p. 13).

${ }^{68} \mathrm{GE}$, I, p. $706 \mathrm{~b}$ (las cursivas son nuestras).
} 
responden los Libros de ajedrez dados e tablas y el Libro de la caza. Hacia el final de su vida, Alfonso llegó incluso a interesarse por la reglamentación de los excesos del ocio en el Libro de las tahurerías. Siempre dentro de este mismo contexto del hombre como ser social, que alterna y se comunica con los demás, Alfonso se ocupa de la música (GE, I, p. 195), la poesía, las diversiones y el placer de las cosas bellas que alivian el ánimo cargado de preocupaciones y trabajos ${ }^{69}$. Es, finalmente, un humanismo que tiene como meta final la sabiduría que lleva a la fama imperecedera y a Dios. Parafraseando un pasaje de la Metafísica de Aristóteles (A, 2, 983), escribe: «Sobresta razón dize el muy sabio Aristótil que semeiar ell omne a Dios que non es ál sinon saber las cosas complidamente e obrar bien, e por esto viene omne a seer con Dios e parcionero con Él en aquella su gloria $\rangle^{70}$.

De estos y otros muchos ejemplos que pudieran espigarse en las obras del Rey Sabio resulta evidente que el humanismo vernáculo de Alfonso X debe verse en un contexto mucho más amplio, cual fue el de las realidades peninsulares y de su situación sociopolítica y religiosa y, en terminos aún más generales, del nuevo espíritu del tiempo (segunda mitad del siglo XII y todo el siglo XIII), caracterizado por una gran revolución cultural, como resultado de la proliferación de nuevos textos de la antigüedad clásica. Es un humanismo que no se limita al estudio de los clásicos y las tradicionales siete artes liberales, sino que tiene múltiples facetas, de las cuales las más importantes son: la filosófico-científica que se manifiesta en un auténtico desborde de traducciones del árabe, primero al latín y después directamente a las lenguas vernáculas; la preocupación por la difusión del saber en lengua vernácula, no solo en castellano sino también en gallego; y la proliferación de hombres de letras que reflejan este espíritu multicultural, multirreligioso y multirracial.

El concepto de «Renacimiento del siglo XII», que a partir de la obra de Ch. H. Haskins ha entrado a formar parte del canon del saber medieval, frecuentemente olvida que dicho «renacimiento» no hubiese sido posible sin las obras que lo alimentaron: se abre con las traducciones del árabe y se cierra con la codificación del saber en castellano por los colaboradores de Alfonso X; en el proceso se crea una lengua nueva que será el vehículo del humanismo científico-literario en la

\footnotetext{
${ }^{69}$ Dice en las Partidas:

Alegrías hí ha otras sin las que diximos en las leyes antes desta [se refiere a la caza], que fueron falladas para tomar home conorte en los cuidados et en los pesares quando los hobiese; et estas son oir cantares et sones de estrumentos, jugar axedrez o tablas, e otros juegos semejantes destos: eso mesmo dezimos de las hestorias et de los romances, et de los libros que hablan de aquellas cosas de que los homes reciben alegría et placer (II, 5, 21).

${ }^{70}$ Los textos pudieran multiplicarse: «Cada uno quanto más [h]a del saber e más se llega a él por estudio, tanto más aprende e crece e se llega por ende más a Dios» (GE, II, 3, p. 31b); «Tod omne que es lleno de vertudes e de saber semeia a Dios, ca por él le viene; et cada uno, quanto más [h]a desto, tanto más semeia a Dios e tanto más se llega a la natura d’Él» (GE, II, 1, p. 290a). Véase el comentario a estos y otros textos en H. S. Martínez, «Paideia y filantropía», pp. 75-96.
} 
trasmisión de la cultura. Hubo un primer impulso para implantar el castellano en la corte y en el scriptorium de su padre, Fernando III, pero no llegó a granar, tal vez porque los tiempos no estaban maduros.

No obstante los obstáculos de toda índole que tuvo que superar el nuevo movimiento cultural puesto en marcha por el Rey Sabio, autóctono y heterodoxo, por su anticonformismo en el contexto cultural del siglo XIII, sin embargo, llegó vigorosamente hasta el siglo XV, cuando por influjo de un hombre excepcional, Antonio de Nebrija, se introdujo en España el otro humanismo, el clasicista. Esta introducción, sin embargo, no se hizo sin que se registraran fuertes protestas y con la abierta oposición por parte de los que eran conscientes de que aquellas novedades importadas alteraban el curso de una tradición humanista autóctona bien establecida y secular.

Alfonso el Sabio, escribe Américo Castro, cumplió en su tiempo con el imperativo de afirmación que exigía el orgánico desarrollo del mundo neolatino; sin este humanismo del siglo XIII habría sido imposible el del XV, provisto ya de otras preocupaciones, fundamentalmente la de teorizar y justificar el valor de lo humano -antes sentido que razonado- como calidad valiosa y autónoma. En tal marco creo que debe ajustarse el ímpetu colosal de la obra alfonsina ${ }^{71}$.

\section{DEFINICIÓN Y CONCLUSIONES}

A la luz de numerosos pasajes que han ido apareciendo en nuestro trabajo, podemos establecer los parámetros de lo que fue el humanismo vernáculo alfonsí y en general el humanismo castellano anterior a Nebrija: es a la vez el culto de la antigüedad greco-romana, el sentimiento del valor y la belleza de la forma en sí misma, y sobre todo el sentimiento correspondiente al valor de la dignidad de la naturaleza y del hombre como tales («La persona del hombre es la más noble cosa del mundo», dirá Alfonso X en la Partida VII, I, XXVI). Este humanismo se nos presenta como una auténtica visión total del hombre y sus quehaceres, terrenos y espirituales, preocupación por las artes y las letras, las ciencias de la naturaleza, la historia, el derecho y la filosofía, así como una pasión por las traducciones de los clásicos latinos y de los filosóficos griegos del árabe al castellano que será el instrumento y vehículo necesario para articular y difundir los nuevos conocimientos.

En el proceso, y esto es lo más significativo, se crea en pleno siglo XIII una nueva lengua de cultura en la que se expresa este movimiento, a la vez científico y literario, y un concepto nuevo de cultura que ahora es vernácula y secular, separada de la latina-teológico-eclesiástica, cuya característica más destacada es el estudio de las ciencias de la naturaleza, teniendo como fundamento la filosofía racional y no los dogmas revelados.

${ }^{71}$ Glosarios latino-españoles de la Edad Media, Madrid, 1936, p. LXV. 
Puesto en estos términos, el humanismo alfonsí no es, desde luego, el de los clasicistas del siglo xv. No solo, sino que se pudiera decir que fueron estos rasgos distintivos la causa por la que no se ha aplicado el término humanista a Alfonso X y humanismo al movimiento cultural lanzado en sus obras. Muchas han sido las causas que históricamente han llevado a los estudiosos a aceptar este estado de cosas. Entre otras, la del aislamiento o «retraso cultural» en que, por razones históricas de la Reconquista, quedó envuelta España; o la de su «excepcionalismo histórico», que ha visto a España como un país al borde entre el Islam y la Cristiandad con un paisaje cultural nebuloso e incomprensible en el complejo de los pueblos de la Europa latino-cristiana ${ }^{72}$. Pero no han faltado en nuestro tiempo otros estudiosos, como Alan David Deyermond, que han reaccionado sin complejos a esta visión negativa de nuestra historia cultural:

Insistimos en el hecho, escribe Deyermond, todavía desconocido por la mayoría de los medievalistas que no son hispanistas, de que España influyó poderosamente en el renacimiento del siglo XII, ya que los textos griegos con comentarios árabes, traducidos al latín en Toledo, resultaron decisivos para la escuela de Chartres y la Universidad de París. Les invito ahora a descartar momentáneamente la certidumbre de que España sufrió un retraso cultural, la creencia arraigada de que la nueva vida intelectual que pasaba por la escuela de traductores de Toledo era únicamente para la exportación ${ }^{73}$.

Sorprende que entre las causas de la exclusión de España del concurso humanístico medieval y del «Renacimiento del siglo XII» no se mencione nunca, por usar un eufemismo benévolo, el desinterés de los «críticos» por explorar su posible existencia; hecho que yace en dos factores fundamentales: el humanismo alfonsí fue integrador de las tres culturas existentes en la Península, y sobre todo fue vernácu$l o$, plantando una doble barrera, cultural y lingüística, insuperable en la Europa latina de los siglos XI al XIV en la que operan los «críticos». La nebulosa de una España mudéjar ha desorientado a estudiosos foráneos y domésticos. Lo que fue para los críticos del pasado barrera insuperable, puede ser para los investigadores de nuestros días una nueva oportunidad para entender el movimiento cultural alfonsí como un verdadero humanismo.

Recibido: 10/01/2017

Aceptado: 1/03/2018

${ }^{72}$ Esta ha sido la actitud predominante en la crítica centroeuropea, sostenida hasta por el mismo Ernst Robert Curtius en su opus magnum donde habla de «El 'retraso' cultural de España» (Literatura europea y Edad Media Latina, 2 vols. México-Madrid, FCE, 1962, vol. II, p. 553 y ss., y pp. 753-756).

${ }^{73}$ Alan D. Deyermond, «El Auto de los reyes magos y el renacimiento del siglo XII», en Actas del IX Congreso de la Asociación Internacional de Hispanistas, Berlín, 18-23 de agosto de 1986, Sebastián Neumeister (ed.), Vervuert, Frankfurt am Main, 1989, p. 186. 
(2)

\title{
HUMANISMO MEDIEVAL Y HUMANISMO VERNÁCULO. OBSERVACIONES SOBRE LA OBRA CULTURAL DE ALFONSO X EL SABIO
}

RESUMEN: Estudio sobre el origen del humanismo vernáculo castellano en el ámbito del humanismo medieval. Se analizan sus características, contrastándolas con las del humanismo latino clasicista del siglo Xv. Se ilustra por qué es un humanismo total, que, por influjo de la filosofía aristotélica, incluye las letras y las ciencias, e integrador de las tres culturas presentes en la sociedad peninsular del siglo XIII, las cuales usaron el vernáculo como lengua común.

Palabras Clave: Humanismo medieval, humanismo vernáculo, humanismo latino clasicista, el castellano lengua de cultura, Alfonso X el Sabio.

\section{MEDIEVAL HUMANISM AND VERNACULAR HUMANISM. REMARKS ON THE CULTURAL WORK OF ALFONSO X THE LEARNED}

\begin{abstract}
A study of the origins of Castilian vernacular humanism in the context of medieval humanism. Its characteristics are analyzed and contrasted with the Latin classicist humanism of the $\mathrm{Xv}^{\text {th }}$ Century. The study illustrates why vernacular humanism, due to the influence of the Aristotelian philosophy, is comprehensive, integrating both the letters and the sciences, and it is inclusive of all three cultures present in the Spanish society of the $\mathrm{XIII}^{\text {th }}$ Century that used the vernacular as their common language.
\end{abstract}

KEYwORDS: Medieval humanism, vernacular humanism, Latin classicist humanism, Castilian as language of culture, Alfonso X the Learned. 